Daniel Gustavo de Oliveira Colnago Rodrigues

\title{
CONTRIBUIÇÃO AO ESTUDO DAS MODALIDADES INTERVENTIVAS NO PROCESSO CIVIL BRASILEIRO Elementos para uma parte geral
}

\author{
Dissertação de Mestrado \\ Orientador: Professor Doutor Marcelo José Magalhães Bonizzi
}

UNIVERSIDADE DE SÃO PAULO

FACULDADE DE DIREITO

São Paulo - SP 
Daniel Gustavo de Oliveira Colnago Rodrigues

\section{CONTRIBUIÇÃO AO ESTUDO DAS MODALIDADES INTERVENTIVAS NO PROCESSO CIVIL BRASILEIRO \\ Elementos para uma parte geral}

Dissertação apresentada a Banca Examinadora do Programa de Pós-Graduação em Direito, da Faculdade de Direito da Universidade de São Paulo, como exigência parcial para obtenção do título de Mestre em Direito, na área de concentração Direito Processual, sob a orientação do Professor Doutor Marcelo José MAgalHÃes BonizZI.

\section{UNIVERSIDADE DE SÃO PAULO}

\section{FACULDADE DE DIREITO}

São Paulo - SP 
Rodrigues, Daniel Gustavo de Oliveira Colnago.

Contribuição ao estudo das modalidades

interventivas no processo civil brasileiro: elementos para uma parte geral / Daniel Gustavo de Oliveira

Colnago Rodrigues ; orientador Marcelo José Magalhães Bonizzi -- São Paulo, 2017.

208 p.

Dissertação (Mestrado - Programa de Pós-

Graduação em Direito Processual) - Faculdade de Direito, Universidade de São Paulo, 2017.

1. Intervenção de terceiros. 2. Modalidades

interventivas atípicas. 3. Parte geral. I. Bonizzi, Marcelo José Magalhães, orient. II. Título. 
AOS MEUS PAIS,

cujos olhos brilham com minhas conquistas. 


\section{AGRADECIMENTOS}

Minha eterna gratidão

A Ele, por iluminar meu caminho nas madrugadas fatigantes de trabalho.

À minha família, especialmente meus pais e irmãos, pelo amor incondicional.

À minha Amanda, pelos nossos sonhos.

Ao meu orientador, Professor Marcelo Bonizzi, pela disponibilidade e segurança.

À Toledo Prudente, na pessoa de Sérgio Tibiriçá, pelo incentivo constante.

Aos colegas do Escritório de Advocacia, pelo fardo da minha ausência.

Ao prezado Silas Santos, por me guiar diariamente nesta jornada.

Ao meu eterno professor, Paulo Pinheiro, pelos livros e pela presteza de sempre.

Aos Professores do Programa de Pós-Graduação em Direito da USP, na pessoa de Cândido Rangel Dinamarco, pelas valiosas lições.

À Professora Paula Costa e Silva, por me receber na Universidade de Lisboa, cumprimento que estendo a Beatriz Galindo e Monique Mosca, pela ajuda em Portugal.

Aos queridos Adriano Camargo, Diego Campos, Elie Eid, Francisco Laux, João Monteiro e Lia Cintra, pelo auxílio na caminhada.

Aos amigos Marcelo Fonseca e Cristiano Rodrigues, pela convivência diária.

Àqueles que, cada um à sua maneira, contribuíram para o trabalho, dentre os quais destaco: Antonio Carvalho, Caíque Leite, Carlos Del Prá, Edilson Vitorelli, Eduardo Alvim, Eduardo Fonseca, Eduardo Talamini, Fábio Caldas, Fernando Gajardoni, Gabriel Lino, Georges Abboud, Gilberto Ligero, Guilherme Recena, Leonardo Cunha, Lucas Buril, Roberto Gouveia, Rodrigo Lucas, Sérgio Ribeiro e Sofia Temer.

Aos meus alunos, por alimentarem minha alma acadêmica. 
Fazer uma obra e reconhecê-la má depois de feita é uma das tragédias da alma. Sobretudo é grande quando se reconhece que essa obra é o melhor que se podia fazer.

FERNANDO PESSOA

(O livro do desassossego. São Paulo: Cia. das Letras, 1999, p. 230). 


\section{RESUMO}

Autor: Daniel Gustavo de Oliveira Colnago Rodrigues; Título: Contribuição ao estudo das modalidades interventivas no processo civil brasileiro: elementos para uma parte geral; Data: 11 de janeiro de 2017; 208 folhas; Grau: Mestrado; Faculdade de Direito da Universidade de São Paulo; São Paulo - 11 de janeiro de 2017

A presente dissertação trata das diversas modalidades de intervenção de terceiros previstas no ordenamento jurídico brasileiro. Em primeiro lugar, são estudadas algumas noções fundamentais sobre o tema interventivo, iniciando-se pela distinção entre parte e terceiro. Após fixar algumas premissas conceituais, o trabalho analisa os fundamentos da intervenção de terceiros, passando por questões afetas à legitimidade e interesse do interveniente, à estabilização subjetiva da demanda, até chegar na classificações das modalidades interventivas, ocasião em que se enfatiza a separação entre intervenções típicas e atípicas. Ultrapassada esta fase inicial, são evidenciados os aspectos principais de cada uma das hipóteses intervencionais típicas, passando-se pela assistência, denunciação da lide, chamamento ao processo, incidente de desconsideração da personalidade jurídica e amicus curiae. Em seguida, o texto investiga as intervenções de terceiro atípicas, de modo a buscar elementos comuns e distintivos em relação às demais modalidades estudadas. São abordadas, neste momento, algumas figuras intituladas pela doutrina e jurisprudência de intervenções atípicas, "sui generis”, especiais, diferenciadas ou anômalas. Destrincha-se, então, o estudo do recurso de terceiro, da intervenção anômala dos entes públicos, da intervenção especial na ação de alimentos, da reconvenção subjetivamente ampliativa, da intervenção litisconsorcial voluntária e, ainda, da pouco explorada intervenção nos procedimentos do Estatuto da Criança e do Adolescente. Ao final, após extrair os caracteres essenciais de cada modalidade interventiva, tenta-se interligar as diversas intervenções objeto de análise, tudo com o propósito de oferecer elementos para uma possível parte geral interventiva.

Palavras-chave: intervenção de terceiros; modalidades interventivas atípicas; parte geral. 


\begin{abstract}
Author: Daniel Gustavo de Oliveira Colnago Rodrigues; Title: Contribution to the study of intervention types in the Brazilian civil procedure: elements for a general party; Date: January 11, 2017; 208 pages; Degree: Master's degree; School of Law of the University of São Paulo; São Paulo - January 11, 2017

This paper deals with the different types of intervention from third parties set forth in the Brazilian legal system. Firstly, some basics on the intervening theme are studied, beginning with the distinction between party and third party. After fixing some conceptual premises, the work analyzes the basics of third-party intervention, going through questions related to the legitimacy and interest of the intervener, to the subjective stabilization of the demand, until reaching the classification of intervention types, at which point the separation between typical and atypical interventions is emphasized. After this initial phase, the main aspects of each of the typical interventional hypotheses are evidenced, going through assistance, impleader, joinder of co-debtor, incident of piercing the corporate veil and amicus curiae. After that, the text investigates the atypical interventions from third parties, in order to seek common and distinctive elements related to the other types studied. At this moment, some figures named by the doctrine and jurisprudence of atypical, "sui generis", special, differentiated or anomalous interventions are addressed. The study of third party appeal, anomalous intervention of public entities, special intervention in the action for support order, subjectively expansive counterclaim, voluntary co-party intervention, as well as the little explored intervention in the Child and Adolescent Statute procedures is then exposed in detail. At the end, after extracting the essential characteristics of each interventional type, an attempt is made to interconnect the various types of interventions under analysis, all with the purpose of offering elements for a possible general intervening party.
\end{abstract}

Keywords: third-party intervention; atypical intervention types; general party. 


\section{SUMÁRIO}

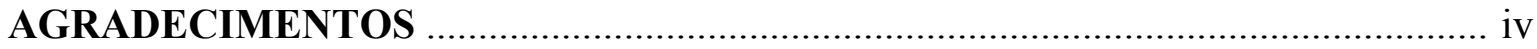

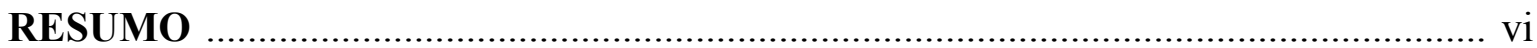

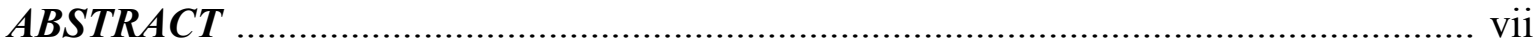

INTRODUÇÃ $\mathbf{O}$

\section{Capítulo I}

\section{NOÇÕES FUNDAMENTAIS SOBRE INTERVENÇÃO DE TERCEIROS}

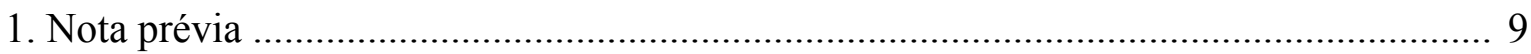

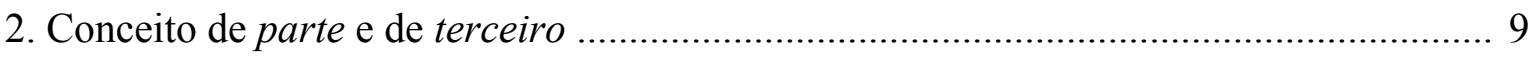

3. O fenômeno interventivo no processo civil brasileiro ................................................ 15

4. Fundamentos da intervenção de terceiros .................................................................. 23

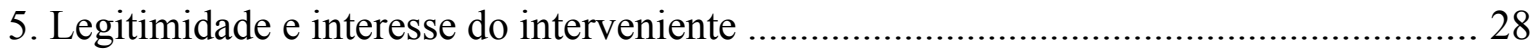

6. Restrições à admissibilidade da intervenção e estabilização subjetiva da demanda ...... 36

7. Classificação das modalidades interventivas .............................................................. 42

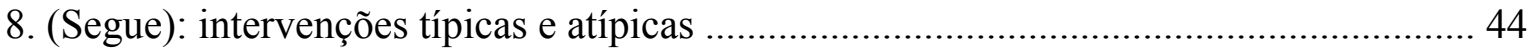

\section{Capítulo II}

MODALIDADES INTERVENTIVAS TÍPICAS: PRINCIPAIS ASPECTOS

1. Considerações preambulares 


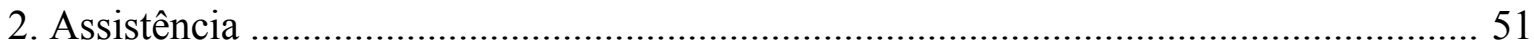

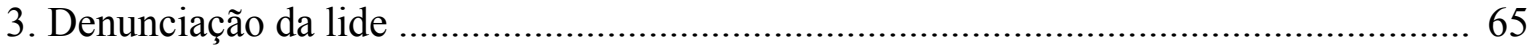

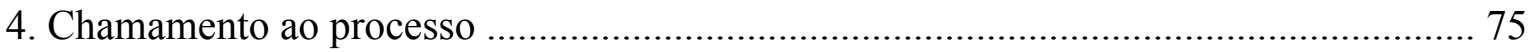

5. Incidente de desconsideração da personalidade jurídica .............................................. 82

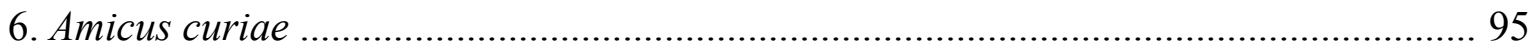

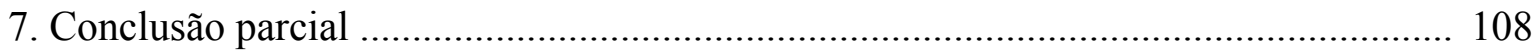

\section{Capítulo III}

\section{INTERVENÇÕES DE TERCEIRO ATÍPICAS}

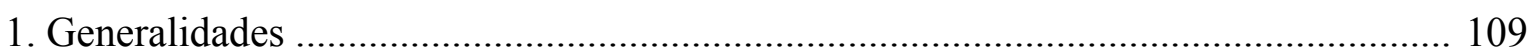

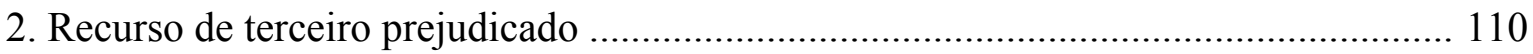

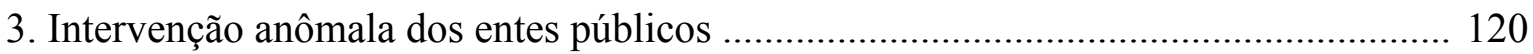

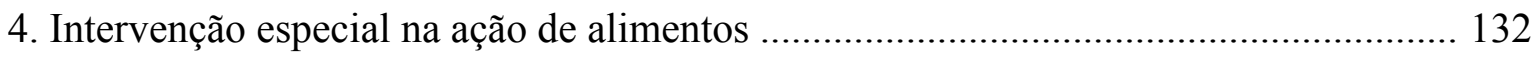

5. Reconvenção subjetivamente ampliativa .............................................................. 147

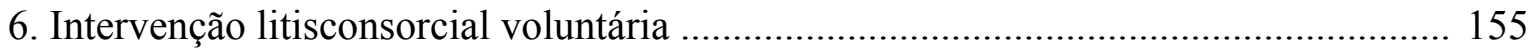

7. Intervenção nos procedimentos do Estatuto da Criança e do Adolescente ................... 167

8. Outras figuras interventivas e fechamento do capítulo .............................................. 172

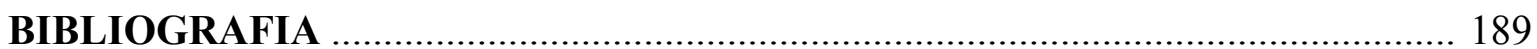




\section{INTRODUÇÃO}

Há mais de quatro décadas, Vicente Greco Filho já atribuía as profundas divergências doutrinárias e legislativas sobre o tema da intervenção de terceiros a dois fatores principais: ( $i$ ) complexidade dos institutos englobados sob esse título; (ii) dificuldade de se fixarem elementos comuns que pudessem conduzir a uma classificação lógica. Assim, ressaltando a disparidade na enumeração dos casos de intervenção de terceiros e as hipóteses que não pertenciam a essa categoria, o autor escreveu opúsculo cuja finalidade era exatamente a "procura de critérios distintivos e comuns entre os casos referidos como de intervenção", a fim de que se pudesse alcançar uma enumeração não empírica de hipóteses agrupáveis sob tal denominação ${ }^{1}$.

Em que pese o brilho da obra produzida, as perplexidades lá expostas parecem ser atemporais.

Ainda soam atuais as palavras de Athos Gusmão Carneiro no sentido de que a intervenção de terceiros mantém-se como um dos assuntos mais árduos do processo civil brasileiro, persistindo intensa divergência entre os autores no que tange à definição, à disciplina legal e até mesmo à classificação dos casos em que um terceiro ingressa em processo pendente ${ }^{2}$. Neste cenário, o presente estudo encontra sua justificativa na ideia de que o recurso a uma parte geral interventiva é uma necessidade conceitual e prática, que se presta, dentre outras importantes funções, a auxiliar os intérpretes na solução de inúmeros problemas envolvendo normas interventivas.

Não se pretende, com isso, afirmar que o tema seja novo, nem que o desiderato científico de estudá-lo se revista de originalidade. A intervenção de terceiros, como se sabe, é instituto bastante antigo: já no direito romano, especialmente no período da cognitio extra ordinem, admitia-se que terceiro ingressasse em processo alheio ${ }^{3}$. Para além de clássico, é tema que sempre mereceu prestígio da doutrina nacional e estrangeira, sendo

\footnotetext{
${ }^{1}$ A intervenção de terceiros no processo civil. São Paulo: Saraiva, 1973, p. 29.

${ }^{2}$ Intervenção de terceiros. $18^{\mathrm{a}}$ ed. São Paulo: Saraiva, 2009, p. XI.

${ }^{3}$ GRECO FILHO, Vicente. Direito processual civil brasileiro. $17^{\mathrm{a}}$ ed. São Paulo, Saraiva, 2003, v. I, p. 126. Cf., ainda: SCIALOJA, Vittorio. Procedimiento civil romano. Buenos Aires: EJEA, 1954, p. 183-184.

${ }^{4}$ No Brasil, considerando apenas obras específicas sobre o tema, em rol exemplificativo: GRECO FILHO, vicente. A intervenção de terceiras no processo civil São Paulo: Saraiva, 1973; DINAMARCO, Cândido Rangetenfintervençao de terceiros. 5 ed. Saro Paulo: Malheiros, 2009; CARNEIRO, Athos Gusmão. GRECO FILHO, Vicente. Direito processual civil brasileiro. $17^{\mathrm{a}}$ ed. São Paulo, Saraiva, 2003, v. I, p. 126. Cf., ainda: SCIALOJA, Vittorio. Procedimiento civil romano. Buenos Aires: EJEA, 1954, p. 183-184.
} 
conhecida farta bibliografia a seu respeito ${ }^{4}$. Fosse simplesmente por isto, razão não haveria para que se encarasse, audaciosamente, o assunto proposto.

Algumas razões, no entanto, legitimam seu reexame na perspectiva de uma parte geral, que abarque, inclusive, as (por vezes esquecidas) modalidades atípicas.

Em primeiro lugar, é notória a ausência de preocupação legislativa a respeito da matéria. Ao contrário do que se dá, por exemplo, com o tema das provas (arts. 369/380), da execução (arts. 771/777) ou dos recursos (arts. 994/1008), inexiste no novo CPC um capítulo afeto às disposições gerais das intervenções de terceiros ${ }^{5}$. Esta tendência de negligenciar uma parte geral sobre o assunto, aliás, não é nova no processo civil brasileiro, já que os Códigos de Processo Civil de 1939 e de 1973 também se mostraram omissos quanto ao tema, limitando-se a regulamentar cada uma das modalidade interventivas. Talvez isto explique a razão pela qual não se vê, na doutrina, sólida construção acerca de uma teoria geral das intervenções de terceiros, conquanto sejam conhecidos os estudos sobre teoria geral das provas, teoria geral da execução e teoria geral dos recursos.

E não é apenas a inexistência de sistematização legislativa que torna o estudo do tema precário. Outros fatores também contribuem para este cenário: $(i)$ dispersão da matéria em legislações extravagantes, a exemplo da denunciação da lide no âmbito do Código de Defesa do Consumidor; (ii) disparidade funcional e estrutural entre as modalidades interventivas, como as assistências simples e litisconsorcial; (iii) necessidade de compreensão das respectivas normas de direito material, tais como as regras sobre solidariedade; (iv) dificuldade de precisar quais sejam as normas interventivas de caráter

\footnotetext{
${ }^{4}$ No Brasil, considerando apenas obras específicas sobre o tema, em rol exemplificativo: GRECO FILHO, Vicente. A intervenção de terceiros no processo civil. São Paulo: Saraiva, 1973; DINAMARCO, Cândido Rangel. Intervenção de terceiros. $5^{\mathrm{a}}$ ed. São Paulo: Malheiros, 2009; CARNEIRO, Athos Gusmão. Intervenção de terceiros. $18^{\mathrm{a}}$ ed., São Paulo: Saraiva, 2009. Na doutrina estrangeira, cf., dentre outras: REDENTI, Enrico. Il giudizio civile con pluralità di parti. Milão: Giuffrè, 1960; MONTERO AROCA, Juan. La intervención adhesiva simple: contribución al estúdio de la pluralidad de partes en el proceso civil. Barcelona: Editorial Hispano Europea, 1972; PRAZERES, Manuel Augusto Gama. Da intervenção de terceiros na relação processual. Porto: Athena, 1972.

${ }^{5}$ Não se desconhece a diferença existente entre teoria geral e parte geral (disposições gerais) de um determinado objeto. Enquanto a primeira é produto da atividade científica, tendo cunho epistemológico, a segunda é fruto da atividade legislativa, consubstanciando-se num conjunto de enunciados normativos. Assim, é possível que haja várias "partes gerais", uma para cada modalidade interventiva, sem que isso implique a negação de uma teoria geral. Nada obstante, embora sejam linguagens inconfundíveis, tais noções influenciam-se reciprocamente, razão pela qual se recomenda, por exemplo, que a parte geral seja estruturada em conformidade com a respectiva teoria geral. Neste sentido, cf. DIDIER JR., Fredie. Sobre a teoria geral do processo, essa desconhecida. $2^{\mathrm{a}}$ ed. Salvador: Juspodivm, 2013, p. 74-75. Na doutrina estrangeira, tratando ambas as perspectivas indistintamente: CASTILLO, Niceto Alcalá-Zamora y. La teoría geneal del proceso y la enseñanza del derecho procesal. Estudios de teoría general de Historia del proceso (1945-1972). Cidade do México: Universidad Nacional Autónoma de México, 1974, t. I, p. 587.
} 
geral, e que por isto mesmo poderiam ser aplicadas subsidiariamente às intervenções atípicas etc. $^{6}$

Em segundo lugar, a importância da presente investigação é fortalecida diante do redimensionamento dogmático conferido ao tema pelo novo sistema processual civil, seja diretamente, em decorrência da generalização do amicus curiae e da alocação do incidente de desconsideração da personalidade jurídica no rol das modalidades de intervenção, ou indiretamente, mediante a consagração de institutos (ex: precedentes obrigatórios) que tendem a impactar consideravelmente o modelo brasileiro de intervenção de terceiros. A propósito disso, já há algum tempo a doutrina vem indicando a necessidade de se repensar certas nuanças teóricas sobre a intervenção de terceiros. Para Sérgio Cruz Arenhart, por exemplo, a adoção de precedentes vinculantes tende a ampliar os efeitos de uma decisão judicial, fazendo repercutir suas consequências sobre a esfera jurídica de terceiros, limitando, por vezes, o direito deles a apresentarem suas razões em processo futuro de que venham a participar. Isto demandaria, por certo, a revisitação do conceito de "interesse jurídico", que se exige para a intervenção e participação de terceiros em processo jurisdicional ${ }^{7}$.

Some-se a tudo isto que boa parte das perplexidades que gravitam em torno da temática "intervenção de terceiros" poderiam ser minimizadas com a instituição de uma parte geral. Pense-se, por exemplo, na polêmica intervenção de terceiro em ação de alimentos, trazida ao direito brasileiro pelo art. 1.698 do Código Civil, sobre a qual ainda inexiste consenso, na doutrina e na jurisprudência, acerca de sua natureza e, consequentemente, de seu regramento. Quiçá a existência de normas gerais interventivas, objetivamente delineadas, pudesse impedir a tentativa de enquadramento (forçado) do instituto em alguma das espécies de intervenção de terceiros já existentes ${ }^{8}$.

Vista por este aspecto, uma parte geral poderia contribuir inclusive para a superação da rigidez pela qual o modelo brasileiro de participação no processo é conhecido. Como se sabe, as normas do Código de Processo Civil atinentes à intervenção

\footnotetext{
${ }^{6}$ Semelhante análise foi feita por Heitor Sica, embora no contexto de uma "teoria geral dos procedimentos especiais" (Reflexões em torno de uma teoria geral dos procedimentos especiais. Revista de Processo. São Paulo: Revista dos Tribunais, jun./2012, vol. 208, p. 61).

${ }^{7} \mathrm{O}$ recurso de terceiro prejudicado e as decisões vinculantes. In: NERY JR., Nelson; WAMBIER, Teresa Arruda Alvim (coord.). Aspectos polêmicos e atuais dos recursos cíveis e assuntos afins. São Paulo: Revista dos Tribunais, 2007, v. 11, p. 436-437.

${ }^{8}$ Foi o que fez, por exemplo, Cassio Scarpinella Bueno (Partes e terceiros no processo civil brasileiro. $2^{\mathrm{a}}$ ed. São Paulo: Saraiva, 2006, p. 334), conforme se verá mais adiante.
} 
de terceiros ainda deixam muito a desejar, seja pela escassez das modalidades previstas, seja pela estrita tipicidade de cabimento da maioria delas ${ }^{9}$. Não há um dispositivo sequer que seja capaz de orientar as formas de intervenção a partir de um critério racional, que leve em conta, por exemplo, a intensidade do interesse do terceiro em relação ao processo inter alios ${ }^{10}$. E este papel poderia ser bem desempenhado por uma parte geral afeta às alterações subjetivas do processo, apta a possibilitar, em última análise, interpretações mais ampliativas das normas sobre intervenção de terceiros.

Lembre-se, ainda, que uma das funções de uma parte geral é nortear não apenas o intérprete e o aplicador, mas também o elaborador da lei, de modo a conferir-lhe um mínimo de racionalidade na criação de institutos e na regulamentação de situações que se relacionem a uma temática geral. Para criar uma nova espécie recursal, por exemplo, o legislador precisa se valer de noções da teoria geral dos recursos (cabimento, desistência, interesse etc.); para estruturar um novo procedimento executivo, o legislador precisa igualmente se guiar por aspectos da teoria geral da execução (menor gravosidade, título executivo, penhora etc.).

No âmbito da intervenção de terceiros, por sua vez, embora a necessidade de suporte teórico se mantenha presente, parece inexistir alicerce dogmático para que novas modalidades interventivas sejam bem instituídas, alarmando-se o problema quando se verifica que o momento é de mudanças legislativas, seja em decorrência da edição do novo Código de Processo Civil, seja em razão das discussões em torno do Código de Defesa do Consumidor e de um Código Comercial.

Sem prejuízo, chama atenção a falta de inter-relação entre as modalidades interventivas. Parafraseando Barbosa Moreira ${ }^{11}$ - que teceu semelhante crítica no contexto dos pressupostos processuais -, quando se diz que um instituto é uma espécie de intervenção de terceiros, a rigor é pouquíssimo o que se fica sabendo a seu respeito. Que se cuida de mecanismo predisposto ao ingresso de um novo sujeito no processo - e só. Sequer existe consenso quanto à condição do interveniente após seu ingresso, vale dizer, se

\footnotetext{
9 Nestes termos, tecendo severas críticas à tipicidade das modalidades interventivas no processo civil brasileiro, cf. SICA, Heitor Vitor Mendonça. Notas críticas ao sistema de pluralidade de partes no processo civil brasileiro. Revista de Processo. São Paulo: Revista dos Tribunais, out./2011, v. 200, p. 13-25.

${ }^{10} \mathrm{Na}$ esteira do que propõe, por exemplo, Cândido Dinamarco (Intervenção de terceiros. $5^{\mathrm{a}}$ ed. São Paulo: Malheiros, 2009, p. 19-22).

${ }^{11}$ BARBOSA MOREIRA, José Carlos. Sobre pressupostos processuais. Temas de direito processual. Quarta série. São Paulo: Saraiva, 1989, p. 93.
} 
adquire a qualidade de parte $^{12}$ ou se permanece como terceiro ${ }^{13}$. O que se aparenta, numa rápida análise, é que foram agrupadas, dentro do mesmo fenômeno, diferentes figuras, com diferentes pressupostos e diferentes efeitos, sendo relevante até mesmo desvendar se existe, neste caso, utilidade prática na reunião de várias espécies processuais sob o mesmo rótulo $^{14}$. Seja como for, esta ausência de coordenação entre as formas de intervenção de terceiros, fruto possivelmente do ostracismo a que foi relegada sua respectiva parte geral, revela que a matéria aqui abordada ainda está a exigir maior amadurecimento.

O objetivo deste trabalho é, portanto, estudar a intervenção de terceiros no processo civil brasileiro, sendo objeto de análise tanto as modalidades previstas no Código de Processo Civil, quanto aquelas previstas em legislações extravagantes, incluindo as hipóteses atípicas, mas sempre com os olhos voltados para a estruturação de uma possível parte gral interventiva. As diversas modalidades de intervenção - tanto as típicas quanto as atípicas - serão analisadas com a finalidade de encontrar predicados comuns, encaminhando-se o estudo para a construção dum arcabouço teórico que justifique minimamente o agrupamento de tais mecanismos sob o mesmo rótulo. Mais que isso: serão perquiridos, cuidadosamente, os pontos de intersecção e de estrangulamento de cada espécie interventiva com o esqueleto teórico então desenhado para o tema. À proporção que a reconstrução teórica for sendo ajustada, pois, as perspectivas práticas serão objeto de reflexão, notadamente para desvendar as possíveis inconsistências legislativas no trato do assunto.

Embora se intente oferecer elementos para uma parte geral das intervenções de terceiros, nada impede que esta construção se dê no espaço restrito do processo civil brasileiro; mais ainda, no específico campo do processo jurisdicional cognitivo de recorte individual. Trata-se, pois, de uma teoria pensada a partir de determinado direito positivo e apenas a ele servível. Naturalmente, até se poderia imaginar uma teoria das intervenções que fosse aplicável a todo e qualquer ordenamento (inclusive o estrangeiro), a todo e qualquer processo (inclusive o arbitral), bem como a todo e qualquer ramo da ciência jurídica (incluindo o trabalhista, por exemplo). Quiçá uma parte geral que abarcasse

\footnotetext{
${ }^{12}$ DINAMARCO, Cândido Rangel. Instituições de direito processual civil. $6^{\mathrm{a}}$ ed. São Paulo: Malheiros, 2009 , v. II, p. 378.

${ }^{13}$ SILVA, Ovídio A. Baptista da. Curso de processo civil. $4^{\mathrm{a}}$ ed. São Paulo: Revista dos Tribunais, 1998, v. 1, p. 271.

${ }^{14}$ No direito italiano, entendendo que a denominação "intervento in causa" designa uma pluralidade de fenômenos: SEGNI, Antonio. Intervento in causa (diritto processuale civile). Novissimo digesto italiano. $3^{\mathrm{a}}$ ed. Torino: Utet, 1957, v. 8, p. 943.
} 
inclusive o processo de execução ${ }^{15}$ ou, ainda, o processo coletivo ${ }^{16}$. Nada obstante, a proposta aqui é declaradamente limitadora: uma parte geral interventiva para o processo jurisdicional, cognitivo, civil e individual brasileiro.

Para tanto, três caminhos precisam ser percorridos: (i) estudar as noções fundamentais sobre o instituto intervencional; (ii) investigar cada modalidade interventiva típica, buscando elementos que possam ser úteis ao desiderato final; (iii) analisar as principais formas atípicas de ingresso de terceiro em processo pendente, para que a proposta de uma parte geral não se revele limitadora e incapaz de abarcar inúmeras situações de direito material previstas no ordenamento brasileiro.

\footnotetext{
${ }^{15}$ Algumas peculiaridades do processo executivo, a exemplo das noções de título executivo e de responsabilidade patrimonial, afora o particular escopo da execução, sugerem, para os limites deste trabalho, seja feito tal corte metodológico. Isto não impede, evidentemente, que sejam feitas, de passagem, menções a determinadas modalidades interventivas cabíveis in executivis.

${ }^{16}$ Embora instigante, o estudo da intervenção de terceiros em processo coletivo não será aqui enfrentado, especialmente em vista das particularidades que acompanham os procedimentos de tutela coletiva. Neste sentido, Ricardo de Barros Leonel observa que "a intervenção de terceiros no processo coletivo ganha cores distintas do que tradicionalmente ocorre no processo clássico. A tutela coletiva tem como grandes motes a prescindibilidade da presença em juízo de todos os interessados e a possibilidade da extensão dos efeitos do julgado a quem não foi 'parte' em sentido formal, com a finalidade última de obter-se a pacificação social com economia processual, evitando-se a todo o custo o conflito prático e teórico de julgados" (Manual do processo coletivo. $3^{\mathrm{a}}$ ed. São Paulo: RT, 2013, p. 251). Também já se disse, ademais, que "o devido processo legal coletivo pressupõe a adequação das normas processuais às particularidades da situação jurídica litigiosa (direito difuso, coletivo ou individuais homogêneos) ou do conflito (local, global, irradiada)" (DIDIER JR., Fredie; ZANETI JR., Hermes. Curso de direito processual civil. $10^{\mathrm{a}}$ ed. Salvador: Juspodivm, 2016, v. 4, p. 215). Há impactos, portanto, nas próprias noções de legitimidade e interesse, razão pela qual se mostra recomendável realizar, aqui, um corte metodológico. Para amplo estudo acerca das especificidades dos litígios coletivos, o que, pensamos, justifica a necessidade de tratamento distinto também quanto à intervenção de terceiros, cf. VITORELLI, Edilson. O devido processo legal coletivo: dos direitos aos litígios coletivos. São Paulo: RT, 2016, p. 35-111.
} 


\section{À GUISA DE CONCLUSÃO: ELEMENTOS PARA UMA PARTE GERAL INTERVENTIVA}

Diversas conclusões específicas quanto a cada modalidade interventiva já foram tomadas ao longo do trabalho. Agora, o arremate dirige-se à tentativa de sistematização das diversas formas intervencionais estudadas, típicas e atípicas. O esforço, registre-se, não se volta a esquadrinhar, de maneira perfeita e acabada, como seriam as disposições gerais afetas ao fenômeno interventivo. O que se busca é, interligando os elementos essenciais extraídos de cada hipótese de intervenção, jogar as primeiras luzes sobre o assunto. É o que se tentará fazer.

Antes, porém, é preciso esclarecer o sentido que aqui se atribui à expressão "parte geral", assim como a possibilidade e conveniência de sua adoção.

Como se viu na parte introdutória deste trabalho, embora as noções de "parte geral" e "teoria geral" não se confundam, elas naturalmente se comunicam. Por vezes, inclusive, são tratadas de maneira indistinta ${ }^{534}$. As disposições gerais interventivas, portanto, à semelhança do que se dá com as "teorias gerais", objetivam organizar os conceitos e enunciados de um determinado objeto científico, não apenas para conferir-lhes unidade, mas sobretudo para estruturá-los com o fardo da coerência, tornando menos árdua, para o observador, a compreensão do fenômeno investigado ${ }^{535}$.

Nesta perspectiva, uma parte geral interventiva representaria um sistema de conceitos e normas elevados ao grau máximo de generalização útil e condensados indutivamente a partir do confronto das diversas espécies interventivas existentes no sistema pátrio. Por certo que tal empreitada teórica convive com o risco, de resto inerente a toda e qualquer teorização, de se perder na abstração. No entanto, este risco tende a se neutralizar na medida em que a construção da teoria se dê mediante a constante observação do real em suas manifestações fenomenológicas. Não por outra razão, uma disciplina teórica das intervenções de terceiros só se reputa útil se, para além de considerar cada

\footnotetext{
${ }^{534}$ É o que faz, conforme já se mencionou, CASTILLO, Niceto Alcalá-Zamora y. La teoría geneal del proceso y la enseñanza del derecho procesal. Estudios de teoría general de Historia del proceso (1945-1972). Cidade do México: Universidad Nacional Autónoma de México, 1974, t. I, p. 587.

${ }^{535}$ POPPER, Karl. A lógica da pesquisa científica. Leonidas Hegenberg e Octanny Silveira da Mota (trad.). São Paulo: Cultrix, s/a, p. 61-62.
} 
modalidade interventiva, tiver aptidão para devolver a cada uma delas os resultados de suas investigações ${ }^{536}$.

A sistematização de uma dada parte geral pode desenvolver-se em termos ascendente (método indutivo) ou descendente (dedutivo). Tanto é possível se esboçar uma parte geral a partir de comparações que busquem elementos comuns e diferenciadores entre duas ou mais espécies de intervenção, como é possível idealizá-la a partir de um sistema mais abrangente (quiçá da própria teoria geral do processo) ${ }^{537}$. Para José Souto Maior Borges, por exemplo, o método indutivo é inviável em qualquer plano do conhecimento, porque, por mais que se teste experimentalmente um fenômeno, não se pode afirmar que ele ocorrerá sempre da mesma forma, nem mesmo num conjunto finito de acontecimentos ${ }^{538}$.

Cândido Dinamarco, por outro lado, defende que a teoria geral [no caso, do processo] é construída por um grau máximo de generalização que parte dos diversos ramos do direito processual (indução). Não aponta nenhum óbice, contudo, a que o processo inverso (dedutivo) seja realizado. Esta segunda hipótese pode ocorrer em razão de fatores como: ( $i$ ) desenvolvimento não simultâneo das categorias normativas, pois se não há espécies diversas, a construção de um gênero é despiciendo; (ii) hipóteses em que, a despeito da coexistência de espécies distintas, há dificuldade de identificar-se um atributo comum, o que obstaculiza, do ponto de vista pragmático, a construção de uma teoria geral; (iii) ausência de problemas comuns às espécies, o que também torna despicienda uma construção normativa de sobreposição já que ela não será objetivamente dirigida à solução de problemas ${ }^{539}$.

Com efeito, no que tange ao tema interventivo, os fatores acima elencados parecem mesmo estar presentes. Precisamente pela dificuldade de identificação de atributos comuns entre as modalidades de intervenção, por vezes mostrou-se necessária a utilização, no caso,

\footnotetext{
${ }^{536}$ Noções formuladas a partir do tratamento dogmático que conferiu Cândido Dinamarco à teoria geral do processo (A instrumentalidade do processo. $14^{\mathrm{a}}$ ed. São Paulo: Malheiros, 2009, p. 68-70).

${ }^{537}$ Neste sentido: LOSANO, Mario G. Sistema e estrutura no direito. São Paulo: Martins Fontes, 2008, v. 1, p. 154. Cf., ainda, JORI, Mario; PINTORE, Anna. Manuale di teoria generale del diritto. $2^{\mathrm{a}}$ ed. Torino: G. Giappichelli Editore, 1995, p. 351-352.

538 Obrigação tributária. $3^{\mathrm{a}}$ ed. São Paulo: Malheiros, 2015, p. 23-33. O autor, todavia, não renuncia ao método indutivo para demonstrar sua teoria geral do direito quando aduz que "as constantes formais são metodologicamente obtidas por um procedimento de abstração que as isola dos conteúdos variados e cambiantes das normas integrantes de um determinado ordenamento jurídicos". Ora, se a teoria geral é construída a partir de um processo de abstração que utiliza como referente as normas integrantes de um determinado ordenamento jurídico, o autor toma como ponto de partida hipóteses particulares, que por abstração, permite que ele chegue a conclusões gerais. Seu método é, portanto, indutivo.

${ }^{539}$ A instrumentalidade do processo. $14^{\text {a }}$ ed. São Paulo: Malheiros, 2009, p. 70.
} 
do método dedutivo, aplicando-se às figuras intervencionais as normas fundamentais do processo, a exemplo do princípio da estabilização da demanda. Isto não impediu, todavia, o emprego do sistema indutivo, consistente na análise dos caracteres essenciais de cada modalidade para, a partir daí, esboçar-se uma parte geral interventiva, propondo-se, ao final, categorias mais genéricas e universalizáveis. Seguiu-se, assim, a advertência de Dinamarco, dita em outro contexto, mas inteiramente aplicável nesta sede: "a teoria geral do processo há de coordenar generalizações indutivas com particularizações dedutivas" 540 .

É verdade que, noutros contextos, a demarcação de uma parte geral já foi objeto de reprovação por parte da doutrina, especialmente pelo seu caráter consideravelmente abstrato. Fazendo referência à classificação germânica do Direito Civil, sobretudo à concepção de Heise, importada do BGB para o Código Civil português, Menezes Cordeiro critica a ideia de uma parte geral. Entende o jurista português que "a Parte Geral deriva de um puro exercício lógico-teorético: é o produto acabado de um discurso central, indiferente à imediata intenção de solucionar casos concretos". Além disto, em termos legislativos, a parte geral depararia com “dificuldades intransponíveis”, já que não seria viável articular uma sequencia de regras efetivamente gerais, dada a diversa natureza das categorias especiais. Do ponto de vista pedagógico, ainda, também haveria problemas, já que a parte geral só proporcionaria mesmo soluções quando conjugada com alguma das partes especiais. Tudo isto conduzira, em suma, a um “juízo global negativo em relação à Parte Geral ${ }^{541}$.

De fato, embora os perigos de uma excessiva abstração sejam mesmo uma realidade, é necessário recordar, como faz Oliveira Ascensão, que sem abstração não há ciência e que apenas através de abstração é possível isolar as normas gerais que dão unidade científica a um determinado sistema. Observou o jurista português, ademais, que as desvantagens da excessiva abstração somente são evitadas mediante a consciência de que a aplicação de qualquer norma da teoria geral a um caso singular só se possa fazer após a ponderação das características do caso, no sentido de concluir que não há elementos que contrariem essa aplicação ${ }^{542}$.

\footnotetext{
${ }^{540}$ DINAMARCO, Cândido Rangel. A instrumentalidade do processo. $14^{\mathrm{a}}$ ed. São Paulo: Malheiros, 2009, p. 70.

${ }^{541}$ Teoria geral do direito civil: relatório, Separata da Revista da Faculdade de Direito da Universidade de Lisboa. Lisboa, 1988, p. 77-80.

${ }^{542}$ Teoria geral do direito civil. Lisboa, 1996, v. 1, p. 24-25.
} 
Ademais, a utilidade de uma parte geral reside, essencialmente, em três aspectos. O primeiro, de ordem conceitual, condiz em identificar o regime jurídico aplicável a determinado instituto que, mesmo assim não rotulado pelo direito positivo, revele ter natureza interventiva. $\mathrm{O}$ segundo, de índole interpretativa, diz respeito à formação de um reservatório normativo acerca do tema, apto a guiar o intérprete no preenchimento de lacunas envolvendo as (já disciplinadas) modalidades interventivas ${ }^{543}$. O terceiro, de corte funcional, consiste em oferecer subsídios para que novas formas de intervenção de terceiros sejam adequadamente criadas pelo legislador. Enfim, seria possível aludir-se a uma parte geral interventiva sem desprezar as peculiaridades e diferenças de cada modalidade.

Agora, sim, vejamos alguns elementos essenciais para configuração de uma (possível) parte geral interventiva, que será aqui estruturada, para fins didáticos, em três seções: admissibilidade, modo de ser e efeitos.

Em primeiro lugar, a admissibilidade.

A intervenção de terceiros, enquanto categoria predisposta a viabilizar o ingresso de terceiro interessado numa causa, tem sua admissibilidade condicionada, em linhas gerais, à situação de direito material deduzida no processo. Isto quer dizer que a participação de terceiro em processo judicial é reflexo, essencialmente, do direito material, por sua vez irredutível a uma teoria geral. Daí se mostrar tão árdua a tarefa de sistematização das modalidades interventivas, chegando Araujo Cintra a dizer que "são elas [modalidades interventivas] a tal ponto heterogêneas e díspares entre si que não permitem a formulação de normas comuns a todas" ${ }^{~} 544$. Sucede que uma parte geral não pressupõe um regime jurídico único aplicável a toda e qualquer modalidade, podendo se satisfazer, a rigor, com elementos comparativos entre as diversas formas intervencionais previstas em lei.

Ainda que em diferentes graus, o móvel de toda e qualquer intervenção envolve, basicamente, uma questão de interesse. E, sobre este ponto, o que o presente estudo pôde nos revelar é a impossibilidade de restringirmos o cabimento de determinada espécie de intervenção, notadamente atípica, com base na estrutura teórica desenvolvida para uma dada modalidade interventiva típica. Acima de tudo, não parece indispensável a exigência de interesse jurídico; não, ao menos, no seu sentido tradicional, relacionado à existência de

\footnotetext{
${ }^{543}$ Em sentido similar, conquanto em sede diversa: HÖRSTER, Heinrich Ewald. A parte geral do Código Civil português: teoria geral do direito civil. Coimbra: Almedina, 1992, p.142.

${ }^{544}$ Do chamamento à autoria: denunciação da lide. São Paulo: Revista dos Tribunais, 1973, p. 4-5.
} 
relação jurídica conexa àquela posta em juízo. Esta assertiva ganhou força com o estudo da intervenção anômala dos entes públicos e, notadamente, da intervenção especial prevista no art. 206 do ECA.

Eis aqui, em nosso modesto sentir, um importante elemento para estruturação de uma parte geral: o interesse para fins de intervenção não se resume ao interesse jurídico "tradicional", historicamente estudado no contexto da assistência. A existência de modalidades interventivas que se contentam com a presença de outro tipo de interesse, como o institucional, no caso do amicus curiae, ou o econômico, no caso da intervenção anômala dos entes públicos, demonstra a impossibilidade de que uma dada parte geral interventiva, ao menos se pensada à luz do direito brasileiro, condicione o ingresso em processo alheio à constatação de um interesse estritamente jurídico.

Ainda na perspectiva de ampliação do conceito de "interesse de intervenção", vale a pena destacar o texto do art. 506 do Novo Código de Processo Civil brasileiro, segundo o qual "a sentença faz coisa julgada às partes entre as quais é dada, não prejudicando terceiros". Ao contrário do que dispunha o art. 472 do CPC/1973, pois, inexiste mais a proibição de que a coisa julgada beneficie terceiros, o que resulta num natural alargamento das hipóteses em que o julgamento da causa projetará efeitos (mesmo que positivos) sobre a esfera de direitos de quem não foi parte no processo. Ora, considerando-se o hipotético benefício que uma demanda alheia pode causar ao terceiro, parece possível concluir que, em certa medida, ficará mais dilatado o cabimento das intervenções de terceiros ${ }^{545}$. Mesmo a noção clássica de "interesse jurídico", então, parece ter sofrido redimensionamento dogmático, de modo que eventual capítulo afeto às disposições gerais interventivas deve abster-se de subordinar as intervenções voluntárias à titularidade, pelo terceiro, de relação jurídica conexa àquela posta em juízo.

Sem sairmos do terreno da admissibilidade, é possível concluir que, embora o legislador tenha certa liberdade para impor a cada modalidade, típica e atípica, requisitos próprios para sua admissão, uma vez preenchidos estes pressupostos, passa a existir verdadeiro direito subjetivo do terceiro à intervenção. A existência de tal direito subjetivo não impede, evidentemente, que o juiz possa, no caso concreto, exercer controle sobre o

\footnotetext{
${ }^{545}$ Substancialmente, a possibilidade de uma decisão influir sobre a esfera jurídica de terceiros sempre foi a ideia que norteou a aceitação das formas de intervenção de terceiros. Como observa Friedrich Lent, "di regola lo svolgimento del processo interessa unicamente le parti ed i loro rappresentanti, senza che i terzi non direttamente toccati dal suo esito - abbiano la possibilita di influirvi. Talvolta, però, questi ultimi risentono degli effetti della pronuncia e devono quindi esser messi in condizione di tutelare i loro interessi" (Diritto processuale civile tedesco. Tradução de Edoardo F. Ricci. Napoli: Morano, 1962, p. 314).
} 
ingresso do terceiro em processo alheio, como na hipótese de a intervenção gerar a formação de um litisconsórcio facultativo que comprometa a rápida solução do litígio (art. $\left.113, \S 1^{\circ}, \mathrm{CPC}\right)$, ou, ainda, na eventualidade de a intromissão do sujeito consubstanciar-se em afronta aos princípios que fundamentam o instituto intervencional (v.g. economia processual). O que não se mostra possível, e isto vale para todas as modalidades, é o juiz inadmitir a intervenção com base em mera discricionariedade.

Há casos em que, para delimitação dos pressupostos interventivos, o legislador se vale de conceitos jurídicos indeterminados, com termos intencionalmente vagos e abertos, a exemplo do que se dá no campo do amicus curiae. Mesmo em tais situações, entretanto, inexiste discricionariedade judicial ${ }^{546}$. Para ficarmos no exemplo do "amigo da corte", não poderia o magistrado, posto reconhecer a presença da relevância da matéria, da especificidade do tema ou, então, da repercussão social da controvérsia, além, sempre, da "representatividade adequada", indeferir o ingresso do terceiro no feito. A eficácia dos princípios constitucionais que orientam o assunto, notadamente o contraditório e a economia processual, impede a adoção de comportamentos incompatíveis com os estados ideais ali perseguidos. Logo, seja porque potencializa o aspecto democrático no processo, seja porque permite a solução de diversos conflitos coligados, a intervenção do terceiro é um direito do interessado, que só pode ser restringido mediante robusto ônus $\operatorname{argumentativo}^{547}$.

Pois parece haver, aqui, outro elemento importante para uma parte geral interventiva: preenchidos os pressupostos legais - que, fique claro, são distintos para cada modalidade -, a intervenção de terceiro no processo é direito do interessado, podendo o juiz controlar apenas se demonstrar, de maneira fundamentada, que o ingresso do sujeito alheio à relação processual não atenderá ao propósito que se destina. Evidentemente, não se considera fundamentada a decisão judicial que empregar conceitos jurídicos indeterminados, sem explicar o motivo concreto de sua incidência no caso (art. 489, § $1^{\circ}$, CPC). Não basta ao juiz, por exemplo, justificar o indeferimento da intervenção do amicus

\footnotetext{
${ }^{546}$ Merece crítica, portanto, o posicionamento do STF, exarado na ADPF 54 (Pleno, Rel. Min. Marco Aurélio de Mello, j. 12.04.2012), no sentido de que a decisão acerca do ingresso do amicus curiae teria caráter discricionário, ficando a critério do relator para evitar tumulto processual. Segundo Georges Abboud, "tratase de verdadeiro contrassenso do STF reconhecer a importância do amicus curiae, e, ao mesmo tempo, colocar seu ingresso à mercê de um julgamento discricionário. Caso o STF decida negar a admissão do amicus, deverá proceder a uma exaustiva fundamentação para evidenciar as razões da negativa" (Processo constitucional brasileiro. São Paulo: RT, 2016, p. 207-208).

${ }^{547}$ Sobre a eficácia dos princípios constitucionais, cf. ÁVILA, Humberto. Teoria dos princípios: da definição à aplicação dos princípios jurídicos. $16^{\mathrm{a}}$ ed. São Paulo: Malheiros, 2015, p. 122-128.
} 
sob o singelo argumento de que não estaria presente, no caso, a representatividade adequada.

A partir do estudo conjunto das modalidades interventivas, ademais, foi possível constatar que, inexistindo regra expressa em sentido contrário, a intervenção que amplie o objeto litigioso do processo somente pode ser admitida até a fase de saneamento. $\mathrm{O}$ incidente de desconsideração da personalidade jurídica é um exemplo de situação que, posto ampliar o objeto do processo, foi expressamente excepcionado pela legislação. Eis a razão de ser, aliás, do art. 134, caput, do CPC, que autoriza o incidente em todas as fases do processo de conhecimento, no cumprimento de sentença e na execução fundada em título executivo extrajudicial. Não houvesse norma similar, por ampliar o objeto do processo, a intervenção estaria vedada após o saneamento, devendo-se, no caso, haver ajuizamento de nova demanda para o fim de se obter a desconsideração da personalidade jurídica. É por isto, aliás, que a chamada “intervenção litisconsorcial voluntária”, como se viu, só pode ser admitida até o momento saneador (art. 329, II, CPC), sob pena de violação à estabilização da demanda.

Isto não impede, é claro, que, na ausência de regras expressas acerca de uma dada modalidade interventiva, seja a analogia aplicada para a colmatação de lacunas. Foi o que se percebeu no estudo da intervenção especial em processo de alimentos (art. 1.698. CC/2002). Diante da existência de elementos essenciais comuns entre esta atípica forma intervencional e o incidente de desconsideração da personalidade jurídica, mormente por ambos representaram hipóteses de intervenção litisconsorcial ulterior provocada pelo autor, é possível adotarmos, para aquela, o modelo teórico do incidente de desconsideração. Trata-se, como visto, de esquema capaz de subsidiar a aplicação de determinadas formas intervencionais atípicas, notadamente aquelas que envolvam convocação de terceiros mediante ação incidental. Logo, conquanto inexista previsão delimitando o momento para ingresso dos alimentantes no processo, a existência de caracteres de ordem comum atrai a aplicação analógica do incidente de desconsideração, inviabilizando-se, no caso, a incidência do princípio da estabilização da demanda.

Pensamos haver, aqui, mais um importante elemento para uma parte geral interventiva: a intervenção do terceiro por ação poderá ocorrer até o saneamento do processo, salvo se a lei, ou a natureza da intervenção, impuser outro momento; se a intervenção se der por inserção, sem ampliação do objeto litigioso, o ingresso será admitido a qualquer momento, ressalvada expressa disposição em sentido contrário. 
Acerca da admissibilidade interventiva, um último ponto merece conclusão.

Trazendo as formas de ingresso atípicas para dentro do terreno interventivo, percebeu-se a inconsistência de regras jurídicas que, peremptoriamente, vedam a intervenção de terceiros em determinados procedimentos especiais. Com efeito, o simples fato de se proibir a intervenção de terceiros, num dado procedimento, não demonstrou ser sinal ostensivo de que, a fortiori, também estariam vedadas as hipóteses intervencionais atípicas. Daí que tanto o recurso de terceiro prejudicado como a reconvenção subjetivamente ampliativa são, em princípio, cabíveis em procedimentos que impeçam a incidência do fenômeno interventivo, ressalvado, claro, expressa disposição em sentido contrário, como fazia o art. 280 do CPC/1973. Em suma, as restrições legais parecem considerar apenas as modalidades típicas; quanto às atípicas, a situação concreta poderia levar o magistrado a restringi-las, desde que, sempre, mediante adequado ônus argumentativo.

O que parece relevante, portanto, é sempre perscrutar os motivos pelos quais se estabeleceu a limitação. Pelo que se pôde constatar a partir do estudo das intervenções típicas, a razão de ser das restrições é, em sua maioria, impedir tumulto processual, notadamente naqueles procedimentos pretensiosamente céleres, que se justificam em razão da necessidade de tutelas jurisdicionais diferenciadas. De lege ferenda, pois, seria de todo conveniente que uma parte geral interventiva dispusesse sobre esse ponto de maneira clara, quiçá estabelecendo que, nos procedimentos especiais em que se vede o fenômeno interventivo, estariam proibidas apenas as modalidades interventivas que ampliassem o objeto do processo. As exceções ficariam por conta das hipóteses em que, posto haver ampliação do objeto, o ingresso de terceiro é condição para validade da decisão, como se dá na reconvenção subjetivamente ampliativa que ocasiona a formação de um litisconsórcio necessário.

De mais a mais, é preciso evidenciar que, em regra, contra a decisão do juiz que admite ou inadmite a intervenção de terceiro, cabe recurso (art. 1.015, IX, CPC). Esta norma, aliás, extraída do capítulo atinente ao agravo de instrumento, tem envergadura de disposição geral interventiva. Vislumbra-se, aqui, importante consequência de se atribuir natureza interventiva a determinada forma atípica de ingresso em processo alheio. Cabe recurso, pois, contra decisão do juiz que admite ou inadmite a intervenção anômala dos entes públicos, a intervenção especial na ação de alimentos, a reconvenção subjetivamente ampliativa, a intervenção litisconsorcial voluntária, a intervenção prevista no art. 206 do 
ECA, dentre outas hipóteses afins. Por vezes, é verdade, a própria lei excepciona a recorribilidade, como se dá na hipótese de intervenção do amicus curiae (art. 138, $\S 1^{\circ}$, CPC), o que não infirma, porém, a possibilidade de se transpor aquela regra recursal para a parte geral interventiva.

Agora, quanto ao modo de ser da intervenção.

A análise pormenorizada das modalidades interventivas típicas, assim como de algumas atípicas, demonstrou a heterogeneidade que acompanha o modo de ser de cada uma delas. Obviamente, uma parte geral não tem mesmo a intenção de unificar o regime jurídico das formas de intervenção. Seu papel, definitivamente, não é este. No entanto, alguns elementos essenciais lá detectados podem ser aqui cotejados.

Em primeiro lugar, conquanto o CPC/2015 não tenha repetido a regra do art. 109 do CPC/1973, no sentido de que o juiz da causa é também competente para as ações que respeitam ao terceiro interveniente, esta norma parece ser a regra geral quando o assunto é intervenção de terceiros e competência. Há, porém, exceções, notadamente no caso de intervenção de ente federal em processo que tramita perante a Justiça Estadual, conforme dispõe o art. 109, inc. I, da Constituição brasileira. O que gera perplexidade é a circunstância de o dispositivo constitucional mencionar apenas algumas formas de intervenção, como a assistência. Some-se a isto o maciço entendimento jurisprudencial, bem discutido no capítulo das intervenções atípicas, segundo o qual a intervenção anômala da União (art. 5º parágrafo único, Lei 9.469/1997) não tem o condão de deslocar a competência para a Justiça Federal, o que só ocorreria no caso de demonstração de legítimo interesse jurídico na causa.

À luz do exposto, parece-nos que, salvo expressa disposição constitucional em sentido contrário, a intervenção de ente federal somente acarretará deslocamento da competência se o interesse levado a juízo for jurídico. Evidentemente, caso a intervenção confira à União (ou alguma de suas entidades) a qualidade de parte, como acontece na denunciação da lide, no chamamento ao processo, ou mesmo na intervenção litisconsorcial voluntária (atípica), perfaz-se o suporte fático da norma prevista no art. 109, I, da CF/1988, de modo que deve haver remessa dos autos à Justiça Federal. Entretanto, no caso de intervenção que não atribua ao interveniente a qualidade de parte, mas de mero terceiro, a natureza do interesse é que determinará se deve haver, ou não, deslocamento da competência. No caso da assistência, sendo o interesse em questão jurídico, competirá aos juízes federais julgar a causa. Já nas hipóteses de amicus curiae, intervenção anômala dos 
entes públicos ou, ainda, intervenção especial do art. 206 do ECA, inexistindo interesse de cunho jurídico, não haverá deslocamento da competência, ainda que o interveniente seja um ente federal.

Aqui também se teria, em nossa visão, mais um importante elemento para uma tal parte geral interventiva: as intervenções que dispensem a existência de interesse jurídico não geram a modificação da competência, salvo expressa disposição constitucional em sentido contrário. Note-se que tal conclusão é especialmente útil para as intervenções atípicas, que, em geral, não possuem regulação detalhada sobre seu modo de ser. Além disto, a bem da coerência, tal normativa teria o condão de constranger o legislador quando da criação de novas hipóteses intervencionais.

Em segundo lugar, parece correto concluirmos que, independentemente do modo específico como se regula cada modalidade interventiva, o fundamental é haver respeito ao contraditório $^{548}$. Sim, pois a diferença procedimental entre cada espécie de intervenção é absolutamente natural. Mesmo no âmbito das disposições gerais sobre recursos ou das disposição gerais sobre provas, por exemplo, não há previsão de identidade procedimental em relação às respectivas espécies. O mesmo deve ser aplicado quanto ao tema interventivo. Logo, não seria recomendável que houvesse padronização quanto ao modo de ser de cada forma intervencional. O que parece indispensável, insista-se, é que se observe o contraditório, sendo esta uma norma extraída dedutivamente da teoria geral do processo e que impacta o sistema interventivo, mormente após o advento do CPC/2015.

Em decorrência do que se acaba de dizer, percebe-se que a aplicação judicial das normas interventivas, notadamente aquelas afetas às modalidades atípicas, deve zelar pelo princípio do contraditório. A título de exemplo, se, em ação de destituição do poder familiar, um parente solicita, com base no art. 206 do ECA, sua intervenção no feito, a despeito de inexistir norma regulamentando como deve se dar tal ingresso, deve o juiz, minimamente, oportunizar que as partes originárias se manifestem a respeito. A propósito, em se tratando de intervenção voluntária, parece possível a utilização do procedimento assistencial (arts. 119-120, CPC) como parâmetro.

Perceba que a análise conjunta das modalidades interventivas, com a inclusão das atípicas, permite que se identifique, mais facilmente, as normas que podem ser

\footnotetext{
${ }^{548}$ Pablo Grande Seara chega a dizer que "la intervención de terceros es una institución de configuración legal, de modo que, siempre que se respete el contenido esencial del derecho de defensa de los terceros, el legislador tiene libertad para elegir el modelo que quiere implantar" (La extensión subjetiva de la cosa juzgada en el proceso civil. Valencia: Tirant to blanch, 2008, p. 177).
} 
analogicamente aplicáveis a cada modalidade, na ausência de regulação específica. Isto ficou bem demonstrado no estudo da intervenção especial do art. 1.698 do Código Civil. Ora, tratando-se de demanda incidental, que dá origem a um litisconsórcio passivo facultativo ulterior simples, tal qual o incidente de desconsideração da personalidade jurídica, como já se viu, deve haver adoção de paradigmas procedimentais equivalentes. Portanto, o modo de ser da intervenção do alimentante deverá seguir, no que couber, os artigos 133 a 137 do Código de Processo Civil. Numa eventual parte geral interventiva, por sinal, seria possível estabelecer norma de encerramento no sentido de que, se a intervenção se der mediante demanda do autor, com formação de litisconsórcio passivo facultativo ulterior simples, aplica-se à hipótese o procedimento do incidente de desconsideração.

Por fim, algumas conclusões atinentes aos efeitos do fenômeno interventivo precisam ser feitas.

A intervenção de terceiros, como se viu, tende a transformar o interveniente em parte. Este é, aliás, um dos principais efeitos interventivos. Sucede que esta corriqueira afirmação doutrinária precisa ser bem compreendida: o termo parte é aqui utilizado no sentido de que o interveniente passa a titularizar posições processuais, embora por vezes limitadas, tornando-se sujeito do contraditório instituído perante o juiz (noção liebmaniana). Note-se que nem sempre a afirmação de que o interveniente torna-se parte quer significar que ele ajuizou demanda ou teve pretensão contra si formulada; em outras palavras, como se pôde perceber, o interveniente nem sempre torna-se parte no sentido chiovendiano. E isto, naturalmente, repercute no estudo das intervenções atípicas.

De plano, verifica-se a impossibilidade de que uma parte geral interventiva atribua, irrestrita e peremptoriamente, a qualidade de parte demandante/demandada a todo aquele que ingresse na causa. A propósito, mesmo no campo das modalidades típicas, a assertiva esboçada mais acima é temperada com o devido grão de sal. Viu-se que o assistente simples, por exemplo, torna-se parte apenas na acepção de Liebman, já que não formula pedido e nem tem, contra si, pedido formulado; daí por que, aliás, parcela da doutrina recorre à expressão "parte auxiliar" para se referir ao assistente simples. Dentro do terreno das intervenções típicas, ainda, chamou atenção a peculiar posição processual do amicus curiae, tido, pela ampla maioria doutrinária, como legítimo terceiro, mesmo depois de seu ingresso no feito. 
O que nos parece relevante pontuar, a partir dessas considerações, é que a ambiguidade do termo parte pode levar a conclusões distorcidas relativamente aos poderes processuais do interveniente.

Sobre esta questão, deve-se considerar, em primeiro lugar, a existência de pedido de tutela jurisdicional formulado pelo (ou contra o) interveniente. Em tais casos, a posição processual do ingressante será, efetivamente, a de parte demandante/demandada (sentido chiovendiano), razão pela qual passará a dispor de amplos poderes no processo (se for o caso, contestar, produzir provas, recorrer etc.). É o que acontece na denunciação da lide, no chamamento ao processo, no incidente de desconsideração da personalidade jurídica, na intervenção especial na ação de alimentos, na reconvenção subjetivamente ampliativa, na intervenção litisconsorcial voluntária, dentre outras.

Em segundo lugar, inexistindo demanda formulada efetivamente pelo (ou em face do) interveniente, é preciso verificar se a relação substancial deduzida no processo pertence (também) a ele, ou, ao menos, se tal relação poderia ser por ele, interveniente, levada a juízo. É o que se dá, em regra, na hipótese de intervenção do colegitimado, sendo exemplos a assistência litisconsorcial e a intervenção especial do art. 206 do ECA. Em casos tais, a despeito de não se tornar parte no sentido chiovendiano, o terceiro interveniente deverá ser tratado como tal, tendo os mesmos poderes processuais que teria caso tivesse proposto a demanda.

Por fim, a terceira categoria por nós detectada é a do legítimo terceiro, ou seja, do interveniente que não se encontra em nenhuma das situações acima indicadas, já que não formulou pedido, não teve pedido contra si formulado, não é colegitimado e nem tem relação jurídica sua discutida no processo. Estes são os casos em que o interveniente, posto ingressar no feito, não passa a ostentar a condição de demandante ou demandado (parte no sentido chiovendiano), permanecendo como terceiro. Apenas poderia ser chamado de parte no sentido liebmaniano, isto é, de sujeitar-se ao contraditório instituído perante o juiz. Nestas hipóteses, de duas, uma: ou a própria lei, ao regular a intervenção, limita os poderes do interveniente, ou o juiz é quem deve defini-los. É o que vemos, no primeiro caso, na assistência simples e na intervenção anômala da União; e, no segundo caso, na intervenção do amicus curiae (art. 138, $\S 2^{\circ}, \mathrm{CPC}$ ). O recurso de terceiro, como visto, pode veicular distintos tipos de interesses, o que reflete, por certo, na posição processual do interveniente. 
Pois a propósito de uma parte geral interventiva, entendemos estar lançado, assim, mais um importante elemento: os poderes processuais do interveniente dependem da natureza da posição por ele adquirida. Se a relação jurídica deduzida em juízo for de titularidade, exclusiva ou não, do interveniente, ou, ainda, se este detiver legitimidade e interesse equivalentes ao da parte, seus poderes serão amplos. Caso contrário, haverá limitação de poderes, senão pela lei, ao menos pelo magistrado. Eis, aqui, mais um ponto importante: de lege ferenda, seria recomendável que um dispositivo geral acerca do tema interventivo atribuísse ao juiz a incumbência de, na esteira do que faz o $\S 2^{\circ}$ do art. 138 , delimitar os poderes processuais de todo interveniente atípico que não adquira a qualidade de parte. De lege lata, cremos ser possível a aplicação analógica de tal dispositivo às modalidades atípicas, insuficientemente reguladas, em que o interveniente não adquire a qualidade de demandante ou demandado, como já visto.

De mais a mais, nas situações em que o interveniente adquirir a condição de demandante ou demandado, ou, pelo menos, receber tratamento de parte (litisconsorte), titularizando, por isto mesmo, amplos poderes na causa, haverá incidência de determinadas regras próprias dos sujeitos parciais do processo, como a regra do prazo em dobro para manifestação, desde que haja litisconsortes representados por distintos escritórios de advocacia (art. 229, CPC); em caso de morte do interveniente, instauração do procedimento de habilitação, com a respectiva suspensão do processo (art. 687-692, CPC); em caso de derrota na causa, distribuição das verbas sucumbenciais entre os litisconsortes (art. 87, $\S 1^{\circ}, \mathrm{CPC}$ ); se for o caso, manifestação sobre audiência de conciliação ou mediação (art. 334, $\S 6^{\circ}, \mathrm{CPC}$ ), dentre outras. De lege ferenda, seria oportuno que um capítulo afeto às disposições gerais interventivas destrinchasse tais aspectos.

Dentro da eficácia interventiva, ademais, é necessário esboçarmos algumas conclusões a respeito da coisa julgada.

Que a eficácia natural (ou reflexa) da sentença atinge o interveniente parece não haver dúvidas. Aliás, como se viu, é justamente o fato de a decisão judicial poder atingir sujeitos outros, além das partes originárias, que justifica, a rigor, a existência da intervenção de terceiros. A questão que se coloca para conclusão, nesta sede, é saber se todo e qualquer interveniente fica vinculado à autoridade da coisa julgada formada no processo em que interveio.

Relativamente às intervenções típicas, exceção feita ao amicus curiae, o assunto já se encontra bastante debatido na doutrina. No caso da assistência, viu-se que o assistente 
simples, por não assumir a condição de parte, não se submete propriamente à coisa julgada, mas apenas à "eficácia da intervenção"; o assistente litisconsorcial, a despeito da polêmica doutrinária, por ter sua relação jurídica discutida no processo, parece vincular-se à imutabilidade do decisum. $\mathrm{O}$ denunciado à lide, o chamado ao processo, assim como o interveniente alcançado pela desconsideração da personalidade jurídica, sendo partes, vinculam-se à coisa julgada, sempre, é claro, dentro dos limites objetivos pertinentes à sua posição. No que tange ao amicus curiae, concluiu-se que, por inexistir pretensão sua discutida em juízo, tal interveniente não se submete à autoridade da coisa julgada. Ainda, não sendo equiparado à figura do assistente simples, e inexistindo previsão legal similar à da assistência, o “amigo da corte” sequer se vincula à eficácia da intervenção.

Pois o que nos parece crucial, aqui também, é a posição processual adquirida pelo interveniente. Em geral, pode-se dizer que o terceiro interveniente será atingido pela coisa julgada sempre que, por meio da intervenção, assumir a condição de parte ${ }^{549}$. E a palavra parte está empregada, neste espaço, no sentido chiovendiano. Isto já nos oferece um norte mais seguro para discussão das intervenções atípicas. Ora, sempre que houver pedido formulado pelo (ou em face do) interveniente, haverá incidência da coisa julgada. São atingidos pela res iudicata, portanto, o interveniente especial na ação de alimentos (alimentante), o interveniente que ingressa por meia da reconvenção subjetivamente ampliativa, o interveniente litisconsorcial voluntário, dentre outros que adquirirem a condição de parte.

$\mathrm{Na}$ hipótese de o interveniente não adquirir a qualidade de demandante ou demandado, como acontece com o assistente simples, o amicus curiae, ou mesmo o interveniente anômalo de que trata o art. $5^{\circ}$, parágrafo único, da Lei 9.469/1997, deve-se investigar se existe alguma norma especial estabelecendo outro tipo de estabilidade (a exemplo da "eficácia da intervenção", prevista no art. 123 do CPC, para o assistente simples). Não havendo normas neste sentido (nem mesmo aplicável por analogia), o terceiro interveniente não se vinculará à coisa julgada. É o que se verifica em relação à intervenção do amicus curiae, que, como se viu, pode, em outro processo, discutir os mesmos argumentos que foram rechaçados na causa em que interveio.

Haveria aqui, igualmente, mais um elemento para uma (possível) parte geral interventiva: em regra, o interveniente é atingido pela coisa julgada, salvo quando houver

${ }^{549}$ TALAMINI, Eduardo. Coisa julgada e sua revisão. São Paulo: RT, 2005, p. 118. 
disposição em sentido contrário, ou quando, pela natureza da posição do ingressante (= terceiro), o objeto julgado não lhe disser respeito. Uma norma desse jaez certamente auxiliaria na resolução de problemas atinentes à incidência, ou não, da coisa julgada em intervenções atípicas. Sem prejuízo, forneceria elementos para delimitação do alcance da (nova) regra segundo a qual os terceiros podem ser beneficiados pela coisa julgada (art. 506, CPC). Sim, porque as inúmeras peculiaridades que acompanham a definição de terceiro, como se viu, tornam o dispositivo insuficiente para resolver os problemas que envolvem a limitação subjetiva da coisa julgada.

Todas as conclusões precedentes demonstram que o tema da intervenção de terceiros segue a exigir, hoje e sempre, maior amadurecimento. Pois com esta monografia objetivou-se jogar luzes sobre obscura questão interventiva, que não vem recebendo a devida atenção por parte da doutrina. A contribuição que se tentou oferecer ao estudo das modalidades interventiva no processo civil brasileiro reside, essencialmente, em instigar os leitores a pensar sobre a conveniência e possibilidade de uma parte geral interventiva. Não se pretendeu - até porque inapropriado a este momento acadêmico - sugerir como deveria ser um capítulo atinentes às disposições gerais interventivas. O que se buscou, em cumprimento a um dos requisitos sugeridos por Umberto Eco para uma investigação desta natureza, foi formular um convite à reflexão sobre esse importante aspecto da intervenção de terceiros. 


\section{BIBLIOGRAFIA}

ABBOUD, Georges. Processo constitucional brasileiro. São Paulo: RT, 2016.

ABRAÃO, Pauliane do Socorro Lisboa. Algumas considerações críticas sobre a natureza jurídica do amicus curiae no direito brasileiro. Revista Dialética de Direito Processual. São Paulo: Oliveira Rocha, dez./2011.

AGUIAR, Mirella de Carvalho. Amicus curiae. Salvador: Juspodivm, 2005.

ALBERTON, Genacéia da Silva. Assistência litisconsorcial. São Paulo: RT, 1994.

ALLORIO, Enrico. La cosa giudicata rispetto ai terzi. Milano: Giuffrè, 1992.

ALVES, Francisco Glauber Pessoa. O cabimento do recurso de terceiro economicamente prejudicado. In: WAMBIER, Teresa Arruda Alvim e DIDIER JR., Fredie (coord). Aspectos polêmicos e atuais sobre os terceiros no processo civil e assuntos afins. São Paulo: Revista dos Tribunais, 2004.

ALVIM, Eduardo Arruda. Breves considerações sobre a assistência e o recurso de terceiro prejudicado. In: DIDIER JR., Fredie et alli (coord.). O terceiro no processo civil brasileiro e assuntos correlatos: estudos em homenagem ao professor Athos Gusmão Carneiro. São Paulo: Revista dos Tribunais, 2010.

. Direito processual civil. 4a ed. São Paulo: RT, 2012.

ALVIM, Thereza. O direito processual de estar em juízo. São Paulo: Revista dos Tribunais, 1996.

AMARAL, Paulo Osternack. Provas: atipicidade, liberdade e instrumentalidade. São Paulo: RT, 2015.

ARAÚJO, Fabio Caldas de. Intervenção de terceiros. São Paulo: Malheiros, 2015.

ARAÚJO, José Henrique Mouta. Meios de defesa do litisconsorte passivo necessário não citado. In: WAMBIER, Teresa Arruda Alvim e DIDIER JR., Fredie (coord). Aspectos polemicos e atuais sobre os terceiros no processo civil e assuntos afins. São Paulo: Revista dos Tribunais, 2004.

ARAÚJO FILHO, Luiz Paulo da Silva. Assistência e intervenção da União. Rio de Janeiro: Forense, 2006. 
ARENHART, Sérgio Cruz. O recurso de terceiro prejudicado e as decisões vinculantes. In: NERY JR., Nelson; WAMBIER, Teresa Arruda Alvim (coord.). Aspectos polêmicos e atuais dos recursos cíveis e assuntos afins. São Paulo: Revista dos Tribunais, 2007, v. 11.

ARMELIN, Donaldo. Legitimidade para agir no direito processual civil brasileiro. São Paulo: Revista dos Tribunais, 1979.

ARRUdA ALVIM, José Manoel. Código de Processo Civil comentado. São Paulo: Revista dos Tribunais, 1976, v. 3.

A posição dos sócios e associados em relação a ações movidas contra as sociedades e associações de que faça parte. In: WAMBIER, Teresa Arruda Alvim e DIDIER JR., Fredie (coord). Aspectos polêmicos e atuais sobre os terceiros no processo civil e assuntos afins. São Paulo: Revista dos Tribunais, 2004.

ASCENSÃO, José de Oliveira. A tipicidade dos direitos reais. Lisboa: Minerva, 1968. . Teoria geral do direito civil. Lisboa, 1996, v. 1.

ASSIS, Araken de. Condições de admissibilidade dos recursos cíveis. In: WAMBIER, Teresa Arruda Alvim; NERY JR., Nelson (coord.). Aspectos polêmicos e atuais dos recursos cíveis de acordo com a Lei 9.756/98. São Paulo: RT, 1999. . Processo civil brasileiro. São Paulo: RT, 2015, v. II, t. I.

ÁVILA, Humberto. Teoria dos princípios: da definição à aplicação dos princípios jurídicos. 16 ed. São Paulo: Malheiros, 2015. . Teoria da segurança jurídica. $3^{\mathrm{a}}$ ed. São Paulo: Malheiros, 2014.

AZEVEDO, Álvaro Villaça. Teoria geral dos contratos típicos e atípicos. São Paulo: Atlas, 2002.

AZEVEDO, Luiz Carlos de. O direito de ser citado. São Paulo: Resenha Universitária, 1980.

BANNER, Stuart. The myth of the neutral amicus: american courts and theis friends, 17901890. Constitucional Commentary, v. 20, 2003.

BARBI, Celso Agrícola. Comentários ao Código de Processo Civil. 10 ed. Rio de Janeiro: Forense, 1998, v. I. 
BARBOSA MOREIRA, José Carlos. Apontamentos para um estudo sistemático da legitimação extraordinária. Revista dos Tribunais. São Paulo: Revista dos Tribunais, 1969, n. 404.

. Direito processual civil (ensaios e pareceres). Rio de Janeiro: Borsoi, 1971.

. Litisconsórcio unitário. Rio de Janeiro: Forense, 1972.

. Estudos sobre o novo Código de Processo Civil. Rio de Janeiro: Líber Juris, 1974.

. A conexão de causas como pressuposto da reconvenção. São Paulo: Saraiva, 1979.

. Sobre pressupostos processuais. Temas de direito processual. Quarta série. São Paulo: Saraiva, 1989.

. Comentários ao Código de Processo Civil. 17ª ed. Rio de Janeiro: Forense, 2013, v. V.

BASTOS, Antonio Adonias Aguiar. A intervenção do fiador como assistente na execução civil com base no art. 834 do CC. In: DIDIER JR., Fredie et alli (coord.). O terceiro no processo civil brasileiro e assuntos correlatos: estudos em homenagem ao professor Athos Gusmão Carneiro. São Paulo: Revista dos Tribunais, 2010.

BEDAQUE, José Roberto dos Santos. Direito e processo: influência do direito material sobre o processo. $2^{\text {a }}$ ed. São Paulo: Malheiros, 2001.

- Sucessão de empresas e desconsideração da personalidade jurídica. In: YARSHELL, Flávio Luiz; PEREIRA, Guilherme Setoguti J. Processo societário. São Paulo: Quartier Latin, 2012.

BEDUSCHI, Carlo. A proposito di tipicità e atipicità dei contratti. Rivista di Diritto Civile. Milão: Giuffrè, 1986, XXXII.

BENEDUZI, Renato. Comentários ao Código de Processo Civil. São Paulo: RT, 2016, t. II.

BENETI, Sidnei Agostinho. Desconsideração da sociedade e legitimidade ad causam: esboço de sistematização. In: DIDIER JR., Fredie; WAMBIER, Teresa Arruda Alvim (coords). Aspectos polêmicos e atuais sobre os terceiros no processo civil e assuntos afins. São Paulo: Revista dos Tribunais, 2004. 
BETTI, Emilio. Trattato dei limiti soggettivi della cosa giudicata in diritto romano. Macerata: Tip. Bianchini, 1922.

BIANQUI, Pedro Henrique Torres. Desconsideração da personalidade jurídica no processo civil. São Paulo: Saraiva, 2011.

BONDIOLI, Luis Guilherme Aidar. Reconvenção no processo civil. São Paulo: Saraiva, 2009.

BONÍCIO, Marcelo José Magalhães. O litisconsórcio na lei de ação civil pública. Revista da Procuradoria Geral do Estado de São Paulo. São Paulo, 1999, v. 51/52.

A dimensão da ampla defesa dos terceiros na execução em face da nova “desconsideração inversa" da personalidade jurídica. In: DIDIER JR., Fredie et alli (coord.). O terceiro no processo civil brasileiro e assuntos correlatos: estudos em homenagem ao professor Athos Gusmão Carneiro. São Paulo: Revista dos Tribunais, 2010 .

. Princípios do processo no novo Código de Processo Civil. São Paulo: Saraiva, 2016.

BONÍCIO, Marcelo José Magalhães; SICA, Heitor Vitor Mendonça. Ensaio sobre os aspectos materiais e processuais do litisconsórcio unitário. In: MENDES, Aluisio Gonçalves de Castro; WAMBIER, Teresa Arruda Alvim. O processo em perspectiva: jornadas brasileiras de direito processual. São Paulo: RT, 2013.

BONIZZI, Marcelo José Magalhães. Evicção e denunciação da lide no novo CPC brasileiro. Revista de Processo. São Paulo: Revista dos Tribunais, ago./2016, vol. 258.

BORGES, José Souto Maior. Obrigação tributária. $3^{\mathrm{a}}$ ed. São Paulo: Malheiros, 2015.

CABRAL, Antonio do Passo. Pelas asas de Hermes: a intervenção do amicus curiae, um terceiro especial. Revista de Processo. São Paulo: Revista dos Tribunais, set.out./2004, vol. 117.

Despolarização do processo, legitimidade ad actum e zonas de interesse: sobre a migração entre polos da demanda. In: YARSHELL, Flávio Luiz; ZUFELATO, Camilo. 40 anos de Teoria Geral do Processo no Brasil. São Paulo: Malheiros, 2013. 
Art. 138. In: STRECK, Lenio Luiz; NUNES, Dierle; CUNHA, Leonardo Carneiro da. Comentários ao Código de Processo Civil. São Paulo: Saraiva, 2016.

CAHALI, Francisco José. Dos alimentos. In: DIAS, Maria Berenice; PEREIRA, Rodrigo da Cunha (coord.). Direito de família e o novo Código Civil. Belo Horizonte: Del Rey - IBDFam, 2001.

CAHALI, Yussef Said. Dos alimentos. 8 ed. São Paulo: RT, 2013.

CALMON DE PASSOS, José Joaquim. Comentários ao Código de Processo Civil. 8 a ed. Rio de Janeiro: Forense, 2001, v. III.

CAMARGO, Luiz Henrique Volpe. Arts. 128, 132 e 135. In: CABRAL, Antonio do Passo; CRAMER, Ronaldo (coord.). Comentários ao novo Código de Processo Civil. Rio de Janeiro: GEN/Forense, 2015.

CÂMARA, Alexandre Freitas. Será o fim da categoria "condição da ação"? Uma resposta a Fredie Didier Junior. Revista de Processo. São Paulo: RT, jul./2011, v. 197. . Lições de direito processual civil. $25^{\mathrm{a}}$ ed. São Paulo: Atlas, 2014, v. 1. - Comentários ao capítulo IV - do incidente de desconsideração da personalidade jurídica e art. 134. In: WAMBIER, Teresa Arruda Alvim et alli (coord.). Breves comentários ao novo Código de Processo Civil. São Paulo: Revista dos Tribunais, 2015.

CARDOSO, Oscar Valente. Amicus curiae e sustentação oral. Revista Dialética de Direito Processual. São Paulo: Oliveira Rocha, dez./2011, vol. 105.

CARNEIRO, Athos Gusmão. O litisconsórcio facultativo ativo ulterior e os princípios do juiz natural e do devido processo legal. Revista de Processo. São Paulo: Revista dos Tribunais, out.-dez./1999, v. 96.

. Mandado de segurança: assistência e amicus curiae. Revista de Processo. São Paulo: Revista dos Tribunais, out.-dez./2003, v. 112. . Intervenção de terceiros. $18^{\mathrm{a}}$ ed. São Paulo: Saraiva, 2009.

CARNEIRO, Paulo Cezar Pinheiro. Art. 138. In: CABRAL, Antonio do Passo; CRAMER, Ronaldo (coord.). Comentários ao novo Código de Processo Civil. Rio de Janeiro: GEN/Forense, 2015. 
CARRIÓ, Genaro R. Notas sobre derecho y lenguaje. Buenos Aires: Abeledo-Perrot, 1976.

CARVALHO, Fabiano; BARIONI, Rodrigo. Eficácia da sentença na denunciação da lide: execução direta do denunciado. In: WAMBIER, Teresa Arruda Alvim e DIDIER JR., Fredie (coord). Aspectos polêmicos e atuais sobre os terceiros no processo civil e assuntos afins. São Paulo: Revista dos Tribunais, 2004.

CARVALHO, José Orlando Rocha de. Alimentos e coisa julgada. São Paulo: Oliveira Mendes, 1998.

CASTILLO, Niceto Alcalá-Zamora y. La teoría geneal del proceso y la enseñanza del derecho procesal. Estudios de teoría general de Historia del proceso (1945-1972). Cidade do México: Universidad Nacional Autónoma de México, 1974, t. I.

CHIOVENDA, Giuseppe. Instituições de direito processual civil. São Paulo: Saraiva, 1965, vol. 2.

CHIZZINI, Augusto. Intervento in causa. Digesto dele discipline privatistiche, sezione civile, v. 10. Estratto. Torino: UTET, 1994.

CINTRA, Antonio Carlos de Araujo. Do chamamento à autoria: denunciação da lide. São Paulo: Revista dos Tribunais, 1973.

CINTRA, Lia Carolina Batista. Análise crítica do vigente sistema brasileiro de intervenção de terceiros. Sistemi processuali a confronto: il nuovo Codice di Procedura Civile dei Brasile tra tradizione e rinnovamento. Brasília: Publicações da Escola da AGU, jan./mar. 2016, v. 8. . Litisconsórcio e intervenção de terceiros no processo autônomo de produção antecipada da prova. In: LUCON, Paulo Henrique dos Santos et alli (coord.). Processo em jornadas. Salvador: Juspodivm, 2016.

COLTRO, Antônio Carlos Mathias. Alimentos no Código Civil de 2002: o direito material e o processual, com enfoque nos terceiros legitimados para a ação e a condição em que a integram, segundo o art. 1.698, última parte, do CC e rápida alusão ao Estatuto do Idoso. In: DIDIER JR., Fredie et alli (coord.). O terceiro no processo civil brasileiro e assuntos correlatos: estudos em homenagem ao professor Athos Gusmão Carneiro. São Paulo: Revista dos Tribunais, 2010. 
CORRÊA DE OLIVEIRA, Lamartine. A dupla crise da pessoa jurídica. São Paulo: Saraiva, 1979.

COSTA, Eduardo José da Fonseca. Assistência nas execuções obrigacionais. Revista de Processo. São Paulo: Revista dos Tribunais, abr./2006, v. 134.

COSTA, Moacyr Lôbo da. A intervenção iussu iudicis no processo civil brasileiro. São Paulo: Saraiva, 1961. . Assistência. São Paulo: Saraiva, 1968.

COSTA, Regina Helena. As prerrogativas e o interesse da justiça. In: SUNDFELD, Carlos Ari; SCARPINELlA BUENO, Cassio (coord.). Direito processual público. São Paulo: Malheiros, 2000.

COSTA, Salvador da. Os incidentes da instância. $8^{\mathrm{a}}$ ed. Coimbra: Almedina, 2016.

COSTA, Sergio. Novissimo digesto italiano. 3. ed. Torino: Utet, 1957. vol. 12.

COSTANZA, Maria. Il contratto atipico. Milão: Giuffrè, 1981.

CRUZ, José Raimundo Gomes da. Pluralidade de partes e intervenção de terceiros. São Paulo: Revista dos Tribunais, 1991.

CRUZ E TUCCI, José Rogério. Da reconvenção. São Paulo: Saraiva, 1984. . Desistência da ação (doutrina e jurisprudência). São Paulo: Saraiva, 1988. . Limites subjetivos da eficácia da sentença e da autoridade da coisa julgada. São Paulo: Revista dos Tribunais, 2006.

CRUZ E TUCCI, José Rogério; AZEVEDO, Luiz Carlos de. Lições de história do processo civil romano. São Paulo: Revista dos Tribunais, 1996.

CUNHA, Leonardo Carneiro da. Intervenção anômala: a intervenção de terceiro pelas pessoas jurídicas de direito público prevista no parágrafo único do art. $5^{\circ}$ da Lei 9.469/1997. In: WAMBIER, Teresa Arruda Alvim e DIDIER JR., Fredie (coord). Aspectos polêmicos e atuais sobre os terceiros no processo civil e assuntos afins. São Paulo: Revista dos Tribunais, 2004.

. Será o fim da categoria condições da ação? Uma intromissão no debate travado entre Fredie Didier Jr. e Alexandre Freitas Câmara. Revista de Processo. São Paulo: RT, ago./2011, v. 198. 
. A Fazenda Pública em juízo. 13ª ed. Rio de Janeiro: Forense, 2016.

CUNHA JR., Dirley da. A intervenção de terceiros no processo de controle abstrato de constitucionalidade - a intervenção do particular, do colegitimado e do amicus curiae na ADI, ADC e ADPF. In: WAMBIER, Teresa Arruda Alvim e DIDIER JR., Fredie (coord). Aspectos polemicos e atuais sobre os terceiros no processo civil e assuntos afins. São Paulo: Revista dos Tribunais, 2004.

D’ÁVILA, Daniela Peretti. A atuação da Comissão de Valores Mobiliários como amicus curiae nos processos judiciais que envolvem o mercado de capitais. São Paulo: Almedina, 2015

DEL PRÁ, Carlos Gustavo Rodrigues. Amicus curiae. Curitiba: Juruá, 2008.

A intervenção da OAB nas causas cíveis envolvendo advogados. In: DIDIER JR., Fredie et alli (coord.). O terceiro no processo civil brasileiro e assuntos correlatos: estudos em homenagem ao professor Athos Gusmão Carneiro. São Paulo: Revista dos Tribunais, 2010.

DERZI, Misabel de Abreu Machado. Direito tributário, direito penal e tipo. São Paulo: RT, 1988.

DIAS, Maria Berenice. O terceiro no processo. Rio de Janeiro: Aide, 1993. Direito das famílias. Porto Alegre: Livraria do Advogado, 2005.

DIDIER JR., Fredie. Recurso de terceiro: juízo de admissibilidade. São Paulo: Revista dos Tribunais, 2002.

. A intervenção judicial do Conselho Administrativo de Defesa Econômica (art. 89 da Lei Federal 8.884/1994) e da Comissão de Valores Mobiliários (art. 31 da Lei Federal 6.385/1976). Revista de Processo. São Paulo: Revista dos Tribunais, maio.jun./2004, v. 115.

. Será o fim da categoria "condição da ação"? Um elogio ao projeto do novo Código de Processo Civil. Revista de Processo. São Paulo: RT, jul./2011, v. 197.

. Sobre a teoria geral do processo, essa desconhecida. $2^{\mathrm{a}}$ ed. Salvador: Juspodivm, 2013.

. Curso de direito processual civil. $17^{\mathrm{a}}$ ed. Salvador: Juspodivm, 2015, v. 1. 
. Le tiers et la procédure civil brésilienne. Civil Procedure Review, v. 6, n. 3: 16-34, sept.-dec., 2015.

DIDIER JR., Fredie; BRAGA, Paula Sarno. Ampliação subjetiva do processo e reconvenção (art. 344, $\S \S 4^{\circ}$ e $5^{\circ}$ do Projeto de Novo CPC). In: FREIRE, Alexandre et alli (coord.). Novas tendências do processo civil: estudos sobre o Projeto do Novo Código de Processo Civil. Salvador: Juspodivm, 2014.

DIDIER JR., Fredie; SOUZA, Marcus Seixas. Formação do precedente e amicus curiae no direito imperial brasileiro: o interessante Dec. 6.142/1876. Revista de Processo. São Paulo: Revista dos Tribunais, jun./2013, v. 220.

DIDIER JR., Fredie; ZANETI JR., Hermes. Curso de direito processual civil. $10^{\mathrm{a}}$ ed. Salvador: Juspodivm, 2016, v. 4.

DINAMARCO, Cândido Rangel. Instituições de direito processual civil. $2^{\mathrm{a}}$ ed. São Paulo: Malheiros, 2003, v. III. . A instrumentalidade do processo. $14^{\mathrm{a}}$ ed. São Paulo: Malheiros, 2009. . Instituições de direito processual civil. $6^{\text {a }}$ ed. São Paulo: Malheiros, 2009, v. II. . Intervenção de terceiros. $5^{\mathrm{a}}$ ed. São Paulo: Malheiros, 2009. . Litisconsórcio. 8a ed. São Paulo: Malheiros, 2009. . Instituições de direito processual civil. $8^{\mathrm{a}}$ ed. São Paulo: Malheiros, 2016, v. I.

DINAMARCO, Pedro Silva. Art. 138. In: CRUZ E TUCCI, José Rogério et alli. Código de Processo Civil anotado. Rio de Janeiro: GZ Editora, 2016.

DINIZ, Maria Helena. Curso de direito civil brasileiro. 25ª ed. São Paulo: Saraiva, 2010, v. 5.

EID, Elie Pierre. Amicus curiae no novo Código de Processo Civil: interesse e poderes. In: LUCON, Paulo Henrique dos Santos et alli (coord.). Processo em jornadas. Salvador: Juspodivm, 2016. . Litisconsórcio unitário: fundamentos, estrutura e regime. São Paulo: RT, 2016.

ESTELLITA, Guilherme. Do litisconsórcio no direito brasileiro. Rio de Janeiro, 1955.

FAIRÉN GUILLÉN, Victor. Notas sobre la intervención principal en el proceso civil. Estudios de derecho procesal. Madrid: Revista de Derecho Privado, 1955. 
FARIAS, Cristiano Chaves de; ROSENVALD, Nelson. Curso de direito civil. $8^{\mathrm{a}}$ ed. Salvador: Juspodivm, 2016, v. 6.

FERRAZ, Sérgio. Assistência litisconsorcial no direito processual civil. São Paulo: Revista dos Tribunais, 1979.

FLAKS, Milton. Denunciação da lide. Rio de Janeiro: Forense, 1984.

FORNACIARI JR., Clito. Sucessão processual. Revista de Processo. São Paulo: Revista dos Tribunais, out-dez./1981, v. 24.

. Da reconvenção no direito processual civil brasileiro. $2^{\mathrm{a}}$ ed. São Paulo: Saraiva, 1983.

. Art. 343. In: CRUZ E TUCCI, José Rogério et alli. Código de Processo Civil anotado. Rio de Janeiro: GZ Editora, 2016.

FREITAS, José Lebre. Introdução ao processo civil: conceitos e princípio. $2^{\mathrm{a}}$ ed. Coimbra: Coimbra Editora, 2009.

FREITAS JR., Horival Marques de. Recurso de terceiro no processo civil brasileiro: limites da intervenção do terceiro e extensão da coisa julgada material. Revista Dialética de Direito Processual. São Paulo: Oliveira Rocha, jul./2012, vol. 112.

FUX, Luiz. Intervenção de terceiros: aspectos do instituto. São Paulo: Saraiva, 1990.

GAJARDONI, Fernando da Fonseca. Anotações sobre as três novas (e discutíveis) hipóteses de intervenção de terceiros previstas no Código Civil de 2002. In: ASSIS, Araken de at alli. (coord.). Direito civil e processo: estudos em homenagem ao professor Arruda Alvim. São Paulo: RT, 2007.

GAJARDONI, Fernando da Fonseca et alli. Teoria geral do processo: comentários ao CPC de 2015. São Paulo: Método, 2015.

GARBAGNATI, Edoardo. La sostituzione processuale. Milano: Giuffrè, 1942.

GODINHO, Robson Renault. O Ministério Público como substituto processual no processo civil. Rio de Janeiro: Lumen Juris, 2007.

GONÇALVES, Aroldo Plínio. Da denunciação da lide. $3^{\mathrm{a}}$ ed. Rio de Janeiro: Forense, 1998.

GONÇALVES, Carlos Roberto. Direito civil brasileiro. São Paulo: Saraiva, 2005, v. 6. 
GONÇALVES, William Couto. Intervenção de terceiros. Belo Horizonte: Del Rey, 1997.

GONZÁLES PILLADO, Esther. La intervención voluntaria de terceros en el proceso civil. Valencia: Tirant lo Blanch, 2006.

GRANDE SEARA, Pablo. La extensión subjetiva de la cosa juzgada en el proceso civil. Valencia: Tirant to blanch, 2008.

GRECO, Leonardo. Concurso e cumulação de ações. Revista de Processo. São Paulo: Revista dos Tribunais, maio/2007, v. 147. . Instituições de processo civil. $2^{\mathrm{a}}$ ed. Rio de Janeiro: Forense, 2011, v. II.

GRECO FILHO, Vicente. A intervenção de terceiros no processo civil. São Paulo: Saraiva, 1973.

. Da intervenção de terceiros. $3^{\mathrm{a}}$ ed. São Paulo: Saraiva, 1991.

. Direito processual civil brasileiro. $17^{\mathrm{a}}$ ed. São Paulo, Saraiva, 2003, v. I.

HANADA, Nélson. Ação de depósito. São Paulo: RT, 1987.

HÖRSTER, Heinrich Ewald. A parte geral do Código Civil português: teoria geral do direito civil. Coimbra: Almedina, 1992.

JAUERNIG, Othmar. Direito processual civil. $25^{\mathrm{a}}$ ed. Trad. F. Silveira Ramos. Coimbra: Almedina, 2002.

JORGE, Flávio Cheim. Chamamento ao processo. São Paulo: Revista dos Tribunais, 1997. . Teoria geral dos recursos cíveis. $6^{\mathrm{a}}$ ed. São Paulo: RT, 2013.

JORGE, Mario Helton. Da denunciação da lide no Código de Defesa do Consumidor. Revista de Processo. São Paulo: Revista dos Tribunais, jun.-ago./2012, vol. 108.

JORI, Mario; PINTORE, Anna. Manuale di teoria generale del diritto. $2^{\mathrm{a}}$ ed. Torino: G. Giappichelli Editore, 1995.

JUSTEN FILHO, Marçal. Desconsideração da personalidade societária no direito brasileiro. São Paulo: Revista dos Tribunais, 1987.

LAMY, Eduardo de Avelar. Intervenção de terceiros e o princípio da fungibilidade: hipóteses de aplicação. In: DIDIER JR., Fredie et alli (coord.). O terceiro no processo civil brasileiro e assuntos correlatos: estudos em homenagem ao professor Athos Gusmão Carneiro. São Paulo: Revista dos Tribunais, 2010. 
LARENZ, Karl. Metodologia da ciência do direito. Tradução de José Lamego. $3^{\mathrm{a}}$ ed. Lisboa: Fundação Calouste Gulbenkian, 1997.

LENT, Friedrich. Diritto processuale civile tedesco. Tradução de Edoardo F. Ricci. Napoli: Morano, 1962.

LEONEL, Ricardo de Barros. Recursos de sobreposição: novo procedimento e intervenção do amicus curiae. In: DIDIER JR., Fredie et alli (coord.). O terceiro no processo civil brasileiro e assuntos correlatos: estudos em homenagem ao professor Athos Gusmão Carneiro. São Paulo: Revista dos Tribunais, 2010.

. Reflexões em torno do denominando "redirecionamento da execução físcal" ao sócio. In: YARSHELL, Flávio Luiz; PEREIRA, Guilherme Setoguti J. Processo societário. São Paulo: Quartier Latin, 2012.

. Manual do processo coletivo. $3^{\mathrm{a}}$ ed. São Paulo: RT, 2013.

LIEBMAN, Enrico Tullio. Processo de execução. $5^{\text {a }}$ ed. São Paulo: Saraiva, 1986.

. Manual de direito processual civil. $3^{\text {a }}$ ed. São Paulo: Malheiros, 2005, v. 1.

LOPES, Bruno Vasconcelos Carrilho. Limites objetivos e eficácia preclusiva da coisa julgada. São Paulo: Saraiva, 2012.

LOPES DA COSTA, Alfredo de Araújo. Da intervenção de terceiros no processo. São Paulo: C. Teixeira e Cia Editores, 1930.

LOPEZ-FRAGOSO, Tomas. La intervención de terceros a instancia de parte en el proceso civil español. Madrid: Marcial Pons, 1990.

LOSANO, Mario G. Sistema e estrutura no direito. São Paulo: Martins Fontes, 2008, v. 1.

LOTUFO, Renan. Alimentos - obrigação avoenga - art. 397 do CCB - possibilidade de dirigir desde logo a pretensão alimentar contra ascendente mais remoto - ônus da prova. Revista Brasileira de Direito de Família. São Paulo: Síntese, jan.-fev.-mar. 2001, v. 8 .

LUCON, Paulo Henrique dos Santos. Relação entre demandas. Brasília: Gazeta Jurídica, 2016.

LUISO, Francesco Paolo. Diritto processuale civile. Settima edizione. Milano: Giuffrè, 2013. 
MACIEL, Adhemar Ferreira. Amicus curiae: um instituto democrático. Revista de Processo. São Paulo: Revista dos Tribunais, abr.-jun./2002, v. 106.

MANDRIOLI, Crisanto. Corso di diritto processuale civile. Torino: G. Giappichelli Editore, 2000, v. 1.

MARCATO, Antonio Carlos. Ação de consignação em pagamento. São Paulo: Malheiros, 1986.

MARINONI, Luiz Guilherme; ARENHART, Sérgio Cruz; MITIDIERO, Daniel. Novo curso de processo civil. São Paulo: RT, 2015, v. 2.

MARQUES, José Frederico. Instituições de direito processual civil. Campinas: Millenium, 1999, v. III.

MAURÍCIO, Ubiratan de Couto. Assistência simples no direito processual civil. São Paulo: Revista dos Tribunais, 1983.

MAZZEI, Rodrigo Reis. O manejo dos declaratórios pelo "terceiro prejudicado". In: WAMBIER, Teresa Arruda Alvim e DIDIER JR., Fredie (coord). Aspectos polêmicos e atuais sobre os terceiros no processo civil e assuntos afins. São Paulo: Revista dos Tribunais, 2004.

A “intervenção móvel” da pessoa jurídica de direito público na ação popular e ação de improbidade administrativa (art. $6^{\circ}, \S 3^{\circ}$, da LAP e art. $17, \S 3^{\circ}$, da LIA). Revista Forense, nov.-dez. 2008, v. 400.

MEDINA, José Miguel Garcia. Chamamento ao processo: questões polêmicas. Revista de Processo. São Paulo: Revista dos Tribunais, jan./2001, v. 101.

MEDEIROS, Hortêncio Catunda de. Recursos atípicos. Rio de Janeiro: Forense, 1980.

MEDINA, Damares. Amicus curiae: amigo da corte ou amigo da parte? São Paulo: Saraiva, 2010.

MELlo, Marcos Bernardes de. Teoria do fato jurídico: plano da existência. $12^{\mathrm{a}}$ ed. São Paulo: Saraiva, 2003.

MENDES, Aluísio Gonçalves. Competência cível da Justiça Federal. São Paulo: Saraiva, 1998.

MENEZES CORDEIRO, António. Teoria geral do direito civil: relatório, Separata da Revista da Faculdade de Direito da Universidade de Lisboa. Lisboa, 1988. 
MONACCIANI, Luigi. Azione e Legittimazione. Milano: Giuffrè, 1951.

MONTERO AROCA, Juan. La intervención adhesiva simple: contribución al estúdio de la pluralidad de partes en el proceso civil. Barcelona: Editorial Hispano Europea, 1972.

MORELLO, Aurélio. Le società atipiche. Milão: Giuffrè, 1983.

MOURA, Mario de Assis. Da intervenção de terceiros (lei civil e processo). São Paulo: Saraiva, 1932.

NENCIONI, Giovanni. L'intervento volontario litisconsorziale nel processo civile. Pádua: CEDAM, 1935.

NERY JR., Nelson. Teoria geral dos recursos. $7^{\mathrm{a}}$ ed. São Paulo: RT, 2014.

NERY JR. Nelson; NERY, Rosa Maria de Andrade. Comentários ao Código de Processo Civil. São Paulo: RT, 2015.

NEVES, Daniel Amorim Assumpção. Manual de direito processual civil. $8^{\mathrm{a}}$ ed. Salvador: Juspodivm, 2016.

NIEVA-FENOL, Jordi. Coisa julgada. Trad. Antonio do Passo Cabral. São Paulo: RT, 2016 .

NOBRE, César Augusto Di Natale. Amicus curiae: uma abordagem processual da figura no âmbito da CVM e do Cade. Revista Dialética de Direito Processual. São Paulo: Oliveira Rocha, mar./2014, vol. 132.

NOGUEIRA, Paulo Lúcio. Estatuto da Criança e do Adolescente comentado. $3^{\mathrm{a}}$ ed. São Paulo: Saraiva, 1996.

OLIVEIRA, Bruno Silveira de. Conexidade e efetividade processual. São Paulo: RT, 2007.

OLIVEIRA, Carlos Alberto Alvaro. Alienação da coisa litigiosa. $2^{\mathrm{a}}$ ed. Rio de Janeiro: Forense, 1986.

OLIVEIRA JR., Waldemar Mariz de. Substituição processual. São Paulo: RT, 1971.

OLIVEIRA NETO, Olavo de. O perfil das novas formas positivas de intervenção de terceiros no Projeto do CPC: desconsideração da personalidade jurídica e amicus curiae. In: AURELLI, Arlete Inês et alli. O direito de estar em juízo e a coisa julgada: estudos em homenagem a Thereza Alvim. São Paulo: RT, 2014. 
PARGENDLER, Ari. A assistência da União Federal nas causas cíveis. Porto Alegre: Ajuris, 1979.

PEREIRA, Milton Luiz. Amicus curiae - intervenção de terceiros. Revista de Processo. São Paulo: Revista dos Tribunais, jan.-mar./2003, v. 109.

PINTO, Teresa Celina Arruda Alvim. O terceiro recorrente. Revista de Processo. São Paulo: Revista dos Tribunais, jul.-set./1990, vol. 59.

PODETTI, J. Ramiro. Tratado de la terceria. $3^{\mathrm{a}}$ ed. Buenos Aires: Ediar, 2004.

PONTES DE MIRANDA, Francisco Cavalcanti. Tratado de direito privado. $4^{\mathrm{a}}$ ed. São Paulo: RT, 1974, t. IX. . Comentários ao Código de Processo Civil. $3^{\mathrm{a}}$ ed. Rio de Janeiro: Forense, 1995, t. I. . Comentários ao Código de Processo Civil. $3^{\mathrm{a}}$ ed. Rio de Janeiro: Forense, 1997, t. II.

POPPER, Karl. A lógica da pesquisa científica. Leonidas Hegenberg e Octanny Silveira da Mota (trad.). São Paulo: Cultrix, s/a.

PORTO, Sérgio Gilberto. Doutrina e prática dos alimentos. $3^{\mathrm{a}}$ ed. São Paulo: RT, 2003.

PRAZERES, Manuel Augusto Gama. Da intervenção de terceiros na relação processual. Porto: Athena, 1972.

QUIJANO, Jairo Parra. La intervención de terceros en el proceso civil. Buenos Aires: Depalma, 1986.

RAMOS MÉNDEZ, Francisco. La sucesión procesal. Barcelona: Hispano Europea, 1974.

REDENTI, Enrico. Il giudizio civile con pluralità di parti. Milão: Giuffrè, 1960.

REIS, José Alberto dos. Intervenção de terceiros. Coimbra: Coimbra Ed., 1948.

ROCHA, José de Albuquerque. Nomeação à autoria. São Paulo: Saraiva, 1983.

RODRIGUES, Daniel Colnago. A assistência provocada no processo civil brasileiro: possibilidade e conveniência. Revista de Processo. São Paulo: Revista dos Tribunais, fev./2015, v. 240.

RODRIGUES, Fernando Pereira. O novo processo civil: os princípios estruturantes. Coimbra: Almedina, 2013. 
RODRIGUES, Marcelo Abelha. Elementos de direito processual civil. $2^{\mathrm{a}}$ ed. São Paulo: RT, 2003, v. 2.

ROSENBERG, Leo. Tratado de derecho procesal civil. Trad. esp. Angela Romera Vera. Buenos Aires: EJEA, 1955, t. I.

ROSSATO, Luciano Alves; LÉPORE, Paulo Eduardo; CUNHA, Rogério Sanches. Estatuto da Criança e do Adolescente comentado artigo por artigo. $3^{\mathrm{a}}$ ed. São Paulo: RT, 2012.

ROSSI, Júlio César. Amicus curiae: atuação por uma jurisprudência íntegra e coerente. Revista Dialética de Direito Processual. São Paulo: Oliveira Rocha, jan./2014, vol. 130.

SALOMÃO FILHO, Calixto. O novo direito societário. 4a ed. São Paulo: Malheiros, 2011.

SANCHES, Sidney. Denunciação da lide no direito processual civil brasileiro. São Paulo: Revista dos Tribunais, 1984.

SANTOS, Marina França. Intervenção de terceiro negociada: possibilidade aberta pelo novo Código de Processo Civil. Revista de Processo. São Paulo: Revista dos Tribunais, mar./2015, v. 241.

SANTOS, Moacyr Amaral. Da reconvenção no direito brasileiro. São Paulo: Max Limonad, 1958.

SANTOS, Silas Silva. Litisconsórcio eventual, alternartivo e sucessivo. São Paulo: Atlas, 2013.

. Modificações subjetivas na execução e o objeto litigioso. Tese (Doutorado). São Paulo: USP, 2016.

SATO, Priscila Kei. O Instituto Nacional da Propriedade Industrial nas ações de nulidade e de adjudicação: parte ou assistente? In: DIDIER JR., Fredie; WAMBIER, Teresa Arruda Alvim (coord.). Aspectos polêmicos e atuais sobre os terceiros no processo civil e assuntos afins. São Paulo: Revista dos Tribunais, 2004.

SATTA, Salvatore. Manual de derecho procesal civil. Trad. de Santiago Sentís Melendo e Fernando de la Rua. Buenos Aires: Ediciones Jurídicas Europa-América, 1972, v. I.

SCARPINELLA BUENO, Cassio. Chamamento ao processo e devedor de alimentos: uma proposta de interpretação para o art. 1.698 do Novo Código Civil. In: WAMBIER, 
Teresa Arruda Alvim e DIDIER JR., Fredie (coord). Aspectos polêmicos e atuais sobre os terceiros no processo civil e assuntos afins. São Paulo: Revista dos Tribunais, 2004.

. Amicus curiae no processo civil brasileiro: um terceiro enigmático. São Paulo:

Saraiva, 2006.

. Partes e terceiros no processo civil brasileiro. $2^{\mathrm{a}}$ ed. São Paulo: Saraiva, 2006.

. A nova lei do mandado de segurança. 2. ${ }^{\mathrm{a}}$ ed. São Paulo: Saraiva, 2010.

. Aspectos gerais da intervenção de terceiros no novo Código de Processo Civil. In:

LUCON, Paulo Henrique dos Santos et alli (coord.). Processo em jornadas.

Salvador: Juspodivm, 2016.

SCIALOJA, Vittorio. Procedimiento civil romano. Buenos Aires: EJEA, 1954.

SEABRA FAGUNDES, M. Dos recursos ordinários em matéria civil. Rio de Janeiro: Forense, 1946.

SEGNI, Antonio. Intervento in causa (diritto processuale civile). Novissimo digesto italiano. $3^{\text {a }}$ ed. Torino: Utet, 1957, v. 8.

Sull'intervento adesivo. Scritti Giuridici. Torino: UTET, 1965, v. 2.

SICA, Heitor Vitor Mendonça. Notas críticas ao sistema de pluralidade de partes no processo civil brasileiro. Revista de Processo. São Paulo: Revista dos Tribunais, out./2011, v. 200.

. O direito de defesa no processo civil brasileiro: um estudo sobre a posição do réu. São Paulo: Atlas, 2011.

. Reflexões em torno de uma teoria geral dos procedimentos especiais. Revista de Processo. São Paulo: Revista dos Tribunais, jun./2012, v. 208.

SILVA, Nelson Finotti. A intervenção de terceiros sob a luz do art. 1.698 do Novo CC e o Estatuto do Idoso. Revista de Processo. São Paulo: Revista dos Tribunais, jan./2005, v. 119.

SILVA, Ovídio A. Baptista da. Curso de processo civil. $4^{\mathrm{a}}$ ed. São Paulo: Revista dos Tribunais, 1998, v. 1.

- Comentários ao Código de Processo Civil. $2^{\mathrm{a}}$ ed. São Paulo: Revista dos Tribunais, 2005, v. I. 
SIQUEIRA, Thiago Ferreira. A responsabilidade patrimonial no novo sistema processual civil. São Paulo: RT, 2016.

SODRÉ, Eduardo. Juizados especiais cíveis - processo de conhecimento. Rio de Janeiro: Lumen Juris, 2005.

SOUZA, André Pagani de. Desconsideração da personalidade jurídica: aspectos processuais. $2^{\mathrm{a}}$ ed. São Paulo: Saraiva, 2011. . Art. 137. In: CRUZ E TUCCI, José Rogério et alli. Código de Processo Civil anotado. Rio de Janeiro: GZ Editora, 2016.

SOUZA, Antonio André Muniz de. O INPI como interveniente especial nas ações de nulidade. Revista de Processo. São Paulo: Revista dos Tribunais, jan./2005, v. 119.

SOUZA, Gelson Amaro de. A assistência e a coisa julgada. Revista Jurídica. Porto Alegre: Notadez Informação, ago. 2003, v. 310.

. Responsabilidade patrimonial no CPC/2015. Revista Dialética de Direito Processual. São Paulo: Oliveira Rocha, jul./2015, vol. 148.

TALAMINI, Eduardo. Coisa julgada e sua revisão. São Paulo: Revista dos Tribunais, 2005.

. Partes e os terceiros no mandado de segurança individual, à luz de sua nova disciplina (Lei 12.016/2009). Revista Dialética de Direito Processual. São Paulo: Oliveira Rocha, nov./2009, vol. 80.

- Art. 138. In: WAMBIER, Teresa Arruda Alvim et alli (coord.). Breves comentários ao novo Código de Processo Civil. São Paulo: Revista dos Tribunais, 2015 .

TARTUCE, Fernanda. Processo civil aplicado ao direito de familia. São Paulo: Método, 2012.

TARZIA, Giuseppe. Lineamenti del processo civile di cognizione. Quarta edizione. Milano Giuffrè: 2009.

TAVARES, Osvaldo Hamilton. A CVM como amicus curiae. Revista dos Tribunais. São Paulo: RT, abr./1993, n. 690.

TEMER, Sofia. Incidente de resolução de demandas repetitivas. Salvador: Juspodivm, 2016. 
THEODORO JR., Humberto. O Novo Código Civil e as regras heterotópicas de natureza processual. In: DIDIER JR., Fredie; MAZZEI, Rodrigo (coord.). Reflexos do Novo Código Civil no direito processual. Salvador: Juspodivm, 2006. - Uma novidade no campo da intervenção de terceiros no processo civil: a denunciação da lide per saltum (ação direta). In: DIDIER JR., Fredie et alli (coord.). O terceiro no processo civil brasileiro e assuntos correlatos: estudos em homenagem ao professor Athos Gusmão Carneiro. São Paulo: Revista dos Tribunais, 2010.

Curso de direito processual civil. 56 ${ }^{\mathrm{a}}$ ed. Rio de Janeiro: Forense, 2015.

USTÁRROZ, Daniel. A intervenção de terceiros no processo civil brasileiro. Porto Alegre: Livraria do Advogado, 2004.

VALL-LLOVERA, Susana Oromí. Intervención voluntaria de terceros en el proceso civil. Madrid: Marcial Pons, 2007.

VIANA, Salomão. Art. 45. In: WAMBIER, Teresa Arruda Alvim et alli (coord.). Breves comentários ao novo Código de Processo Civil. São Paulo: Revista dos Tribunais, 2015.

VIEIRA, Christian Garcia. Desconsideração da personalidade jurídica no novo CPC: natureza, procedimentos e temas polêmicos. Salvador: Juspodivm, 2017.

VITORELLI, Edilson. O devido processo legal coletivo: dos direitos aos litígios coletivos. São Paulo: RT, 2016.

YARSHELL, Flávio Luiz. Tutela jurisdicional. São Paulo: Atlas, 1998. . Antecipação da prova sem o requisito da urgência e direito autônomo à prova. São Paulo: Malheiros, 2009. Arts. 133, 134, 135 e 137. In: CABRAL, Antonio do Passo; CRAMER, Ronaldo (coord.). Comentários ao novo Código de Processo Civil. Rio de Janeiro: GEN/Forense, 2015.

WAGNER JR., Luiz Guilherme da Costa. Considerações sobre a intervenção de terceiros trazida no art. 1.698 do CC: “a questão da complementação dos alimentos pelos parentes”. In: DIDIER JR., Fredie et alli (coord.). O terceiro no processo civil brasileiro e assuntos correlatos: estudos em homenagem ao professor Athos Gusmão Carneiro. São Paulo: Revista dos Tribunais, 2010. 
WALD, Arnoldo. Da competência das agências reguladoras para intervir na mudança de controle das empresas concessionárias. Revista de Direito Mercantil, Industrial, Econômico e Financeiro. São Paulo: Malheiros, 2002, v. 128.

WAMBIER, Luiz Rodrigues; TALAMINI, Eduardo. Curso avançado de processo civil. $16^{\mathrm{a}}$ ed. São Paulo: RT, 2016, v. 1.

WAMBIER, Teresa Arruda Alvim. Amicus curiae - afinal, quem é ele? Revista do Instituto dos Advogados do Paraná. Curitiba, dez./2006, n. 34.

WAMBIER, Teresa Arruda Alvim; MEDINA, José Miguel Garcia. Amicus curiae. In: DIDIER JR., Fredie et alli (coord.). O terceiro no processo civil brasileiro e assuntos correlatos: estudos em homenagem ao professor Athos Gusmão Carneiro. São Paulo: Revista dos Tribunais, 2010.

WAMBIER, Teresa Arruda Alvim et alli. Primeiros comentários ao novo Código de Processo Civil: artigo por artigo. São Paulo: Revista dos Tribunais, 2015.

ZAFFARONI, Raul. Art. 206. In: CURY, Munir (coord.). Estatuto da Criança e do Adolescente comentado. São Paulo: Malheiros, 2013. 